\title{
SERUM PROTEIN CHANGES IN CAPLAN'S SYNDROME
}

\author{
BY \\ J. A. L. GORRINGE* \\ From the Pneumoconiosis Research Unit, Llandough Hospital, Penarth, Glam.
}

Since Caplan first described characteristic multiple, discrete, round opacities in the lungs of miners with rheumatoid arthritis (Caplan, 1953), numerous attempts have been made to determine the aetiology of these lesions. The association of the characteristic radiological opacities with rheumatoid arthritis (R.A.) was confirmed in the epidemiological studies of Miall, Caplan, Cochrane, Kilpatrick, and Oldham (1953), and of Miall (1955), and in the latter a hereditary factor was clearly shown to be implicated in the development of both "Caplan" lesions and rheumatoid arthritis. The same factor seemed also to predispose to tuberculosis.

Gough, Rivers, and Seal (1955), reporting on the pathology in sixteen cases of the syndrome coming to biopsy or autopsy, found evidence of past or present tuberculosis in about $\mathbf{4 0}$ per cent., which is a similar incidence to that found at autopsy in cases of orthodox progressive massive fibrosis (P.M.F.) (Rivers, James, Davies, and Thomson, 1957), but they described also areas of inflammation in some lesions which did not resemble tuberculosis and which are not found in P.M.F. The inflammation was tentatively identified as the "rheumatoid component".

The identification of $\alpha$-e-diaminopimelic acid (D.A.P.) in lesions showing no histological or bacteriological evidence of tuberculosis (Consden and Glynn, 1955; Consden and Howard, 1957) was interpreted as indicating that mycobacteria had at one time been present, though this amino-acid could have been derived from a variety of other micro-organisms. Nethercott and Strawbridge, as an extension of their work with sarcoidosis (1956), claimed to have identified mycolic acid in Caplan lesions (personal communication). This would have greatly strengthened the tuberculous theory of their aetiology, but the identification of mycolic acid was disputed by Consden (1957) and Berg (1957).

The investigation now reported was an attempt to approach the problem of the aetiology of Caplan lesions from a different angle. The work of Seibert, Seibert, Atno, and Campbell (1947), and of Gilliland,

- Present appointment: Director of Clinical Investigation, Parke Davis and Co., Staines Road, Hounslow, Middlesex.
Johnston, Stradling, and Abdel-Wahab (1956) indicated that tuberculosis caused quite consistent changes in serum proteins, namely increased $\alpha_{2}-$ and $\gamma$-globulins and reduced albumin. That similar changes occur in coal-workers' pneumoconiosis and silicosis associated with tuberculosis was confirmed by Christiaens, Balgairies, Claeys, and Lenoir (1954), and by Rosenkranz (1957) respectively. Shaw (1956) claimed that especially large increases in $\alpha_{2}$-globulin occurred in the presence of tuberculous pleural effusion, and Prignot (1956) stated that $\alpha_{2}$-globulin reached its highest level in miners when cavitation of P.M.F. occurred. As the pulmonary component of Caplan's syndrome is an active and rapidly progressive one compared with P.M.F., giving rise to cavitation earlier and more often (Caplan, 1959) and being not infrequently associated with pleurisy and pleural effusion, it seemed reasonable to look for serum protein changes resembling those found in tuberculosis.

It was realized that rheumatoid arthritis itself causes serum protein changes very similar to those described in tuberculosis (Ropes, Perlmann, Kaufman, and Bauer, 1954; Kuhns and Crittenden, 1955), but it was hoped that the effect of the pulmonary disease would be large enough to be detected in spite of this. An investigation was therefore undertaken of the serum proteins of patients with Caplan's syndrome and to these were added for comparison a small group of patients having characteristic lung. lesions without arthritis and, at the other end of the scale, a small group of miners with rheumatoid arthritis who, in spite of significant dust exposure, had no radiological evidence of nodular pulmonary lesions.

Of fifty men admitted to the trial, five were later excluded, two because of other diseases likely to affect the serum proteins, two because of doubt as to the nature of lung lesions on the basis of which they were at first included, and one because of doubt as to the diagnosis of rheumatoid arthritis.

As a new electrophoretic technique was to be used (Gorringe, 1957), a group of twelve normal subjects was also studied to provide evidence as to the values. to be expected for the various protein fractions in healthy individuals. 
Method of Investigation

The patients were investigated in the following seven ways:

(1) Industrial history to establish exposure to a real dust hazard.

(2) Medical history, including family history.

(3) Clinical examination.

(4) Erythrocyte sedimentation rate $(\mathrm{mm}$. in $1 \mathrm{hr}$ Westergren).

(5) Sheep Cell Agglutination Test (S.C.A.T.) by the method of Ball (1950).

(6) Serum electrophoresis by the method previously described (Gorringe, 1957).

(7) Postero-anterior chest $x$ ray supplemented by lateral $x$ rays and tomograms when thought necessary.

The first four investigations were done on the same day in every case and blood for electrophoresis and S.C.A.T. was obtained at the same time. The serum was separated and stored, frozen solid, until required. Chest $x$ rays of all out-patients were taken on the same day and those of in-patients on admission. The remaining investigations of the in-patients were usually done several days later.

Haematological investigations were performed on all in-patients, but on out-patients only when there was clinical evidence of anaemia. Joints were $x$-rayed in the majority of cases, but the $x$ rays were used in diagnosis only when other investigations left this in doubt.

The stained electrophoresis strips, when dry, were rendered translucent with the clearing fluid described by Rees and Laurence (1955) and scanned in a recording densitometer (Laurence, 1954), using a compound filter consisting of one thickness of Ilford No. 205 gelatin and one thickness of Chance heat-resisting glass. The clearing fluid was then removed by washing the strip in three changes of ether. The trace produced was used as a template for dividing the stained strip reproducibly into five segments corresponding to the five protein fractions. This was done by completing the curves, dropping perpendiculars through the points of intersection on to the baseline, and then transferring these lines on to the stained strip, which was positioned over the trace by means of a pencil line drawn on the strip beyond the albumin band before scanning and so represented on the trace by a sharp peak (Fig. 1, opposite). Each stained strip was then divided longitudinally into equal halves by another pencil line and cut up into ten segments. The five segments in each half paper corresponding to the five protein fractions were eluted separately and estimated in a spectrophotometer at $640 \mathrm{~m} \mu$. The two sets of optical densities obtained were compared and, if compatible, added together. The value for each fraction was then expressed as a percentage of the total. The object of eluting each paper in two halves was two-fold; in the first place it was necessary to keep the highest optical density within the accurate range of the spectrophotometer. This could have been achieved by using twice the quantity of eluting fluid or thinner cuvettes, but it was felt that duplicate estimations would constitute a useful check against gross error.

Total protein estimations were done by the specific gravity method (Phillips, Van Slyke, Dole, Emerson Hamilton, and Archibald, 1944, 1945), but there seemed: no object in expressing protein fractions in absolut $\overline{\bar{B}}$ concentrations since this practice tends to obscure differences by making all the values numerically smale No relationship was found between total protein value and severity of disease so that the percentage values have the same validity as the absolute values.

\section{Diagnosis and Grading}

\section{(A) Rheumatoid Arthritis}

In order to include mild and inactive cases of R.A. in the study, the strict diagnostic criteria of Miall (1955) and of Kellgren and Lawrence (1956\% had to be relaxed to some extent, but all except two of the more severe cases (Grade 2 and above see below) had two or more of their three criteria- $\vec{G}$ history of characteristic polyarthritis plus charactero istic radiological joint changes and/or a positive sheep cell agglutination test (S.C.A.T.). It was felt that the clinical diagnosis was sufficiently certain if the case of the two exceptions to justify theif inclusion.

Clinical diagnosis was based on:

(1) A history of past or present polyarthritig with morning stiffness, pain in and/os swelling of joints affected;

(2) The examination of all joints, especiall: those of the hands and feet for tenderness limitation of movement, crepitus, swelling redness, heat, effusions, muscle wasting, ang deformity;

(3) Examination of the skin for palma erythema, hyperhydrosis, pigmentation rheumatoid nodules, psoriasis, or other skiñ disease;

(4) Examination for enlargement of livet. spleen, and lymph nodes.

All patients in whom R.A. was diagnosed were first graded as Active or Inactive (the latter aro subsequently designated " $R$ "-for "Remission" Remission was inferred when a patient had not. more than one sign or symptom in each of the following groups:

Group 1. Joints

Morning stiffness of one or more joints.

Pain and/or tenderness in one or more joints?

Swelling of one or more joints.

Functional disability not attributable residual deformity.

Group 2. Systemic

Rheumatoid nodules.

Abnormal fatigue and lassitude.

Hyperhydrosis.

Palmar erythema. 


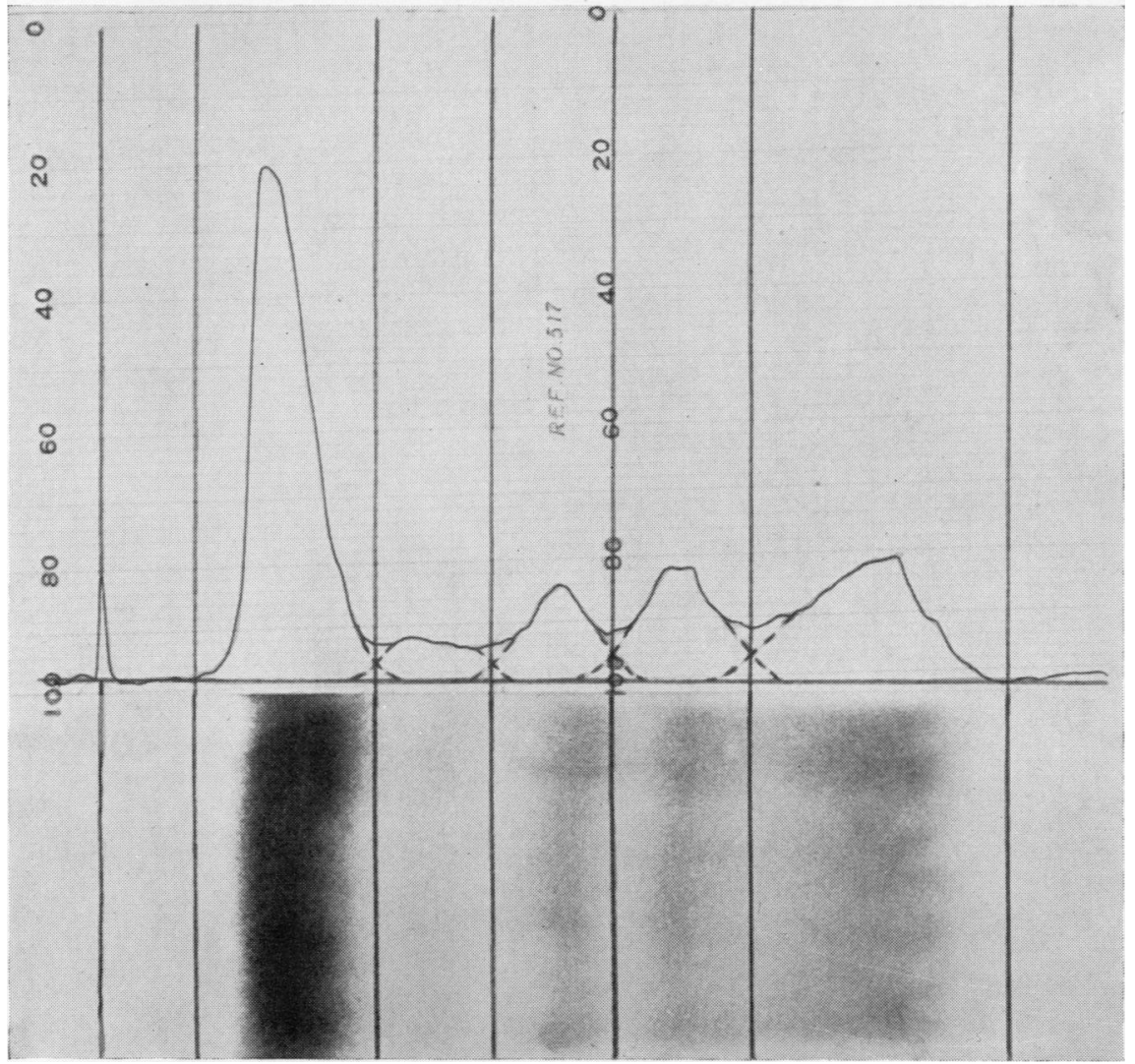

Fig. 1.-Stained electrophoresis strip and corresponding densitometer trace illustrating method used for dividing strip reproducibly by protein fractions for elution.

Limitation of movement, crepitus, muscle wasting, and deformity were regarded as compatible with R.A. in remission. Hot, red joints and intraarticular effusions were always regarded as indicating activity.

This exclusively clinical assessment of activity was necessitated by ignorance as to the effect exerted by the lung pathology upon the erythrocyte sedimentation rate, white cell count, and possibly other criteria often employed such as the haemoglobin level (Duthie, Brown, Knox, and Thompson, 1957). The identical mean erythrocyte sedimentation rate level found in those without arthritis and those with arthritis graded as inactive (Fig. 4, below) suggests that the assessment was valid.

Cases judged to be active were further classified according to the severity of the disease as follows:

Grade 1. "Doubtful."-Complaints of pain, swelling, or stiffness of joints. No disability and minimal clinical signs.
Grade 2. "Slight."-Complaints of pain, swelling, or stiffness of joints, with slight disability and mild but definite clinical signs.

Grade 3. "Moderate."-Complaints of pain, swelling, or stiffness of joints, with moderate disability and obvious clinical signs.

Grade 4. "Severe."-Severe pain, swelling, and stiffness of numerous joints, with severe disability and gross clinical signs.

Patients with no past or present history of arthritis were designated "Grade 0".

This grading is similar to that used by Kellgren and Lawrence (1956), but there is, in fact, nothing "doubtful" about the diagnosis of the five patients in Grade 1, since this group was made up as follows:

Two cases of recent onset ( 3 weeks and 2 days) both of which subsequently developed more severe disease and one of which (the latter) developed rheumatoid nodules simultaneously with his minimal joint symptoms. 
Two cases with a positive S.C.A.T.

One case in which the disease had formerly been more severe, but which could not be classified as a case of remission.

The grades represent points on a continuous spectrum and differences of opinion might well exist between observers as to the grading of any one case. All cases were, however, examined and graded by a single observer. Since each grading represents an opinion at a particular point in time, it is not possible to estimate reproducibility, but subsequent grading of twenty of the patients who were followed up for periods up to 2 years shows satisfactorily consistent results except when remission has occurred. The distribution of cases by grades in the whole series is shown in Table $I$.

TABLE I

DISTRIBUTION OF CASES BY GRADE OF ARTHRITIS

\begin{tabular}{lll|c|c|c|c|c|c|c}
\hline Grade $\ldots$ & $\cdots$ & 0 & $R$ & 1 & 2 & 3 & 4 & All Grades \\
\hline No. of Cases & $\ldots$ & 6 & 6 & 5 & 14 & 10 & 4 & 45 \\
\hline
\end{tabular}

\section{(B) Lung Lesions}

The grading of chest radiographs presented certain difficulties. The I.L.O. classification of complicated pneumoconiosis proved unsuitable for the purposes of the present study because the usually large number of nodules in cases of Caplan's syndrome resulted in nearly all cases falling into "Grade C". Simply counting the nodular lesions proved imprac- ticable because of coalescence and superimposition A compromise scheme was devised and the films. were divided into five grades:

Grade 0.-No massive lesions-simple pneumo coniosis or normal $x$ ray.

Grade I.-Earliest detectable massive lesionsnon-specific "A" shadows.

Grade II.-Three or fewer specific nodules on either side.

Grade III.-More than three specific nodules ot one or both sides.

Grade IV.-As Grade III, but with confluence o nodular lesions.

All the $x$ rays were read on the same day by the same observer on two separate occasions severag, months apart. This scheme of grading yielde $\Phi$ 85 per cent. reproducibility. The seven film graded differently on the two occasions were later read a third time and an agreed grade was arrived af

Of the 45 subjects, seven had rheumatoid arthritis without characteristic lung lesions (Grade II o5 above), six had characteristic lung lesions without past or present arthritis, and 32 had Caplan'g syndrome.

\section{Results}

The results of the investigation are summarized i⿱乛龰 Table II, and Table III (overleaf), which include a $\$$ the data from which the figures were drawn and the $\overrightarrow{\vec{E}}$ conclusions reached.

TABLE II

SUMMARY OF INVESTIGATION OF FIFTY PATIENTS, EXCLUDING SERUM PROTEIN ANALYSES

\begin{tabular}{|c|c|c|c|c|c|c|c|c|c|}
\hline \multirow{2}{*}{$\begin{array}{l}\text { Case } \\
\text { No. }\end{array}$} & \multirow{2}{*}{$\begin{array}{l}\text { Lung } \\
\text { Lesion } \\
\text { Grade }\end{array}$} & \multirow{2}{*}{$\begin{array}{l}\text { R.A. } \\
\text { Grade }\end{array}$} & \multirow{2}{*}{$\begin{array}{l}\text { Erythrocyte } \\
\text { Sedimenta- } \\
\text { tion Rate } \\
\text { (mm. in 1hr., } \\
\text { Westergren) }\end{array}$} & \multirow{2}{*}{$\begin{array}{l}\text { S.C.A.T. } \\
\text { Reciprocal } \\
\text { Titre at } \\
18 \mathrm{hrs}\end{array}$} & \multirow{2}{*}{ Nodules } & \multirow{2}{*}{ Psoriasis } & \multicolumn{2}{|c|}{ Family History } & \multirow{2}{*}{ Remarks } \\
\hline & & & & & & & R.A. & $\begin{array}{l}\text { Tuber- } \\
\text { culosis }\end{array}$ & \\
\hline 1 & IV & 2 & 32 & 256 & - & & & & Left basal pleurisy \\
\hline 2 & $\mathrm{I}$ & 3 & 47 & 128 & - & & & & Felty's syndrome Rubber allergy $\frac{I}{C}$ \\
\hline 3 & III & 3 & 54 & 64 & - & & & & $\begin{array}{l}\text { Allergy to aspirin, phenylbutazone, } \\
\text { and gold }\end{array}$ \\
\hline 4 & IV & 4 & 37 & 32 & - & & - & $\cdots$ & \\
\hline 5 & III & $\mathbf{R}$ & 20 & 16 P.P. & + & & + & & $\begin{array}{c}\text { Encysted left basal effusion for } \\
3 \text { years }\end{array}$ \\
\hline 6 & II & $\mathbf{R}$ & 10 & $>4$ & - & & & & \\
\hline 7 & IV C. & 4 & 38 & 32 & - & $\div$ & & & Died 1 month later \\
\hline 8 & III & $\mathbf{R}$ & 16 & 256 & + & & & & $\begin{array}{l}\text { Right basal pleurisy with effusion } \\
2 \text { yrs and } 9 \mathrm{mths} \text { before } \\
\text { Lung biopsy } 1 \text { yr before }\end{array}$ \\
\hline 9 & III & 2 & 48 & 512 & -P.P. & & & & \\
\hline 10 & IV & 2 & 28 & 8 & - & & & - & \\
\hline 11 & IV C. & 3 & 25 & 256 & + & & & & $\begin{array}{l}\text { Error in erythrocyte sedimentation } \\
\text { rate suspected. Following week } \\
52 \mathrm{~mm} \text {. }\end{array}$ \\
\hline
\end{tabular}




\begin{tabular}{|c|c|c|c|c|c|c|c|c|c|}
\hline 12 & IV C. & 2 & 65 & 64 & + & & & & Herpes zoster at time of examination \\
\hline 13 & IV C. & 3 & 39 & 64 & + & & & & \\
\hline 14 & IV C. & 3 & 106 & 256 & + & & & & $\begin{array}{l}\text { Familial ichthyosis. Died } 2 \mathrm{mths} \\
\text { later }\end{array}$ \\
\hline 15 & IV C. & 4 & 55 & 64 & + & + & & & $\begin{array}{l}\text { A.F.B. in gastric lavage on one } \\
\text { occasion. Virulence unknown }\end{array}$ \\
\hline 16 & I & $\mathbf{R}$ & 10 & 16 P.P. & -P.P. & & & & \\
\hline 17 & II & 0 & 3 & $<4$ & - & & & & \\
\hline 18 & III & 2 & 40 & 32 & - & & & & \\
\hline 19 & Excluded. & \multicolumn{7}{|c|}{ Other disease-?Myelomatosis. } & \\
\hline 20 & IV & 2 & 21 & $<4$ & - & & & & $\begin{array}{l}\text { Sputum positive } 2 \text { days later. Died } \\
1 \text { year later }\end{array}$ \\
\hline 21 & III & $\mathbf{R}$ & 16 & 64 & - & & & & \\
\hline 22 & III & 2 & 30 & 128 & - & + & & & $\begin{array}{l}\text { Pleurisy } 4 \text { years before. R.A. in } \\
\text { remission from } 1930 \text { to } 1953\end{array}$ \\
\hline 23 & II & 0 & 19 & 256 & - & & & & $\begin{array}{l}\text { Cervical spondylosis causing sen- } \\
\text { sory loss of ulnar distribution }\end{array}$ \\
\hline 24 & IV Cal. & 3 & 42 & 256 & + & & & + & \\
\hline 25 & II & 1 & 3 & 32 & - & & & & $\begin{array}{l}\text { Allergy to penicillin, streptomycin, } \\
\text { P.A.S., and ZnO strapping }\end{array}$ \\
\hline 26 & III & 1 & 41 & 8 & - & & & & \\
\hline 27 & II C. & 2 & 39 & 32 & - & & & & , \\
\hline 28 & IV C. & 0 & 24 & $<4$ & $?+$ & & & & Pleurisy, 1946 \\
\hline 29 & III C. & 2 & 64 & 128 & + & & + & & \\
\hline 30 & III & 3 & 47 & 128 & + & & & & \\
\hline 31 & Excluded. & \multicolumn{7}{|c|}{ Other disease-Bronchial carcinoma. } & \\
\hline 32 & 0 & 2 & 19 & $<4$ & - & + & & & \\
\hline 33 & III C. & 2 & 69 & 64 & -P.P. & & & & Calcified hilar lymph nodes \\
\hline 34 & Excluded. & \multicolumn{7}{|c|}{ Diagnosis in doubt. } & \\
\hline 35 & I & 2 & 30 & 64 & - & & & + & \\
\hline 36 & 0 & 1 & 33 & $<4$ & + & & & & $\begin{array}{l}\text { Hypertensive. Died } 4 \text { months } \\
\text { later }\end{array}$ \\
\hline 37 & 0 & 1 & 8 & $<4$ & - & + & & & \\
\hline 38 & 0 & 4 & 57 & $<4$ & $?+$ & & & & \\
\hline 39 & IV & 2 & 35 & 256 & - & & + & & $\begin{array}{l}\text { Sputum positive } 6 \text { years previously. } \\
\text { Urticaria }\end{array}$ \\
\hline 40 & III & 3 & 21 & 512 & + & & + & + & Pleurisy at age 21 \\
\hline 41 & III Cal. & 0 & 9 & 128 & - & & & & \\
\hline 42 & III & 0 & 5 & 32 & - & + & & & S.C.A.T. formerly as high as 1,024 \\
\hline 43 & Excluded. & \multicolumn{7}{|c|}{ Diagnosis in doubt. } & \\
\hline 44 & Excluded. & \multicolumn{7}{|c|}{ Diagnosis in doubt. } & \\
\hline 45 & II & 2 & 23 & 64 & + & & & & \\
\hline 46 & III & 1 & 44 & 64 & - & & & & \\
\hline 47 & IV & 0 & 36 & 128 & - & & + & & \\
\hline 48 & III & $\mathbf{R}$ & 24 & 32 & + & & + & & \\
\hline 49 & III Cal. & 3 & 104 & 512 & + & & & & \\
\hline 50 & III C. & 3 & 68 & 256 & + & & $?+$ & & $\begin{array}{l}\text { One son had rheumatic fever and } \\
\text { died of rheumatic heart disease }\end{array}$ \\
\hline
\end{tabular}


TABLE III

SERUM PROTEIN ANALYSIS OF 45 PATIENTS

\begin{tabular}{|c|c|c|c|c|c|c|c|c|}
\hline \multirow{2}{*}{$\begin{array}{c}\text { Case } \\
\text { No. }\end{array}$} & \multirow{2}{*}{$\begin{array}{c}\text { Total } \\
\text { Protein } \\
\text { (g./100 ml.) }\end{array}$} & \multicolumn{5}{|c|}{ Serum Protein Fractions } & \multirow{2}{*}{ A/G Ratio } & \multirow{2}{*}{$A / x_{2}-G$} \\
\hline & & A & $\alpha_{1-G}$ & $x: 2-G$ & $\beta-G$ & $\gamma-G$ & & \\
\hline 1 & $6 \cdot 66$ & $53 \cdot 17$ & $6 \cdot 25$ & $9 \cdot 17$ & $11 \cdot 20$ & $20 \cdot 21$ & $1 \cdot 135$ & $5 \cdot 80$ \\
\hline 2 & 7.02 & $59 \cdot 45$ & $4 \cdot 50$ & $8 \cdot 06$ & $7 \cdot 22$ & $20 \cdot 75$ & 1.466 & $7 \cdot 36$ \\
\hline 3 & $6 \cdot 84$ & $46 \cdot 55$ & $7 \cdot 17$ & $10 \cdot 22$ & $9 \cdot 60$ & $26 \cdot 46$ & $1 \cdot 148$ & $4 \cdot 55$ \\
\hline 4 & $6 \cdot 84$ & 56.05 & $4 \cdot 00$ & 9.77 & 11.60 & $18 \cdot 57$ & $1 \cdot 275$ & 5.74 \\
\hline & 7.02 & $61 \cdot 10$ & $3 \cdot 46$ & $8 \cdot 33$ & $9 \cdot 12$ & $18 \cdot 00$ & 1.570 & $7 \cdot 34$ \\
\hline 6 & $7 \cdot 02$ & $67 \cdot 23$ & $2 \cdot 81$ & $7 \cdot 27$ & $7 \cdot 33$ & $15 \cdot 36$ & 2.050 & $9 \cdot 25$ \\
\hline 7 & $7 \cdot 20$ & $43 \cdot 45$ & $4 \cdot 74$ & $14 \cdot 23$ & 11.61 & 25.95 & 0.770 & 3.05 \\
\hline 8 & $7 \cdot 20$ & $51 \cdot 50$ & $5 \cdot 70$ & 10.01 & $12 \cdot 34$ & $20 \cdot 45$ & 1.063 & $5 \cdot 14$ \\
\hline$\stackrel{\circ}{9}$ & $7 \cdot 74$ & $51 \cdot 15$ & $5 \cdot 16$ & 9.80 & 11.97 & 21.92 & 1.046 & $5 \cdot 22$ \\
\hline 10 & $7 \cdot 38$ & 55.48 & 4.07 & 9.53 & 9.92 & $21 \cdot 00$ & $1 \cdot 246$ & 5.82 \\
\hline 11 & $7 \cdot 20$ & $51 \cdot 50$ & $4 \cdot 64$ & $10 \cdot 81$ & 12.69 & $20 \cdot 36$ & 1.063 & $4 \cdot 7 \overline{6}$ \\
\hline 12 & $7 \cdot 38$ & $50 \cdot 25$ & $5 \cdot 54$ & $11 \cdot 22$ & $8 \cdot 78$ & $24 \cdot 20$ & 1.010 & $4 \cdot 48$ \\
\hline 13 & $7 \cdot 56$ & 57.90 & 4.71 & $9 \cdot 52$ & 9.57 & $18 \cdot 30$ & 1.375 & 6.08 \\
\hline 14 & $7 \cdot 56$ & $44 \cdot 14$ & $5 \cdot 25$ & 14.01 & $9 \cdot 30$ & $27 \cdot 30$ & $0 \cdot 790$ & $3 \cdot 15$ \\
\hline 15 & $7 \cdot 38$ & 46.68 & $5 \cdot 27$ & 10.82 & 8.95 & $28 \cdot 28$ & 0.876 & $4 \cdot 32$ \\
\hline 16 & $7 \cdot 56$ & $63 \cdot 50$ & $3 \cdot 23$ & $7 \cdot 38$ & $7 \cdot 65$ & $18 \cdot 25$ & $1 \cdot 740$ & 8.60 \\
\hline 17 & $7 \cdot 02$ & $65 \cdot 46$ & $4 \cdot 29$ & $8 \cdot 12$ & $8 \cdot 53$ & $13 \cdot 59$ & 1.895 & 8.06 \\
\hline 18 & $8 \cdot 46$ & $48 \cdot 33$ & 4.97 & $11 \cdot 58$ & $11 \cdot 38$ & $23 \cdot 74$ & 0.936 & $4 \cdot 17$ \\
\hline 20 & $7 \cdot 38$ & 50.01 & $5 \cdot 85$ & $11 \cdot 38$ & $9 \cdot 28$ & 23.45 & 1.003 & $4 \cdot 39$ \\
\hline 21 & $7 \cdot 20$ & 57.95 & $4 \cdot 41$ & 8.41 & $11 \cdot 27$ & 17.94 & 1.427 & 6.89 \\
\hline 22 & $6 \cdot 84$ & $62 \cdot 01$ & 4.96 & $8 \cdot 76$ & 10.61 & 13.66 & 1.633 & 7.08 \\
\hline 23 & 6.84 & $70 \cdot 85$ & $3 \cdot 08$ & $8 \cdot 19$ & $6 \cdot 39$ & 11.50 & $2 \cdot 430$ & 8.65 \\
\hline 24 & $7 \cdot 38$ & 53.40 & 3.73 & $9 \cdot 40$ & 11.49 & 21.98 & $1 \cdot 147$ & $5 \cdot 68$ \\
\hline 25 & $6 \cdot 84$ & $71 \cdot 25$ & $3 \cdot 60$ & $6 \cdot 54$ & $8 \cdot 89$ & 9.72 & $2 \cdot 478$ & $10 \cdot 89$ \\
\hline 26 & 7.02 & $61 \cdot 84$ & 3.90 & $9 \cdot 13$ & $6 \cdot 46$ & $18 \cdot 67$ & $1 \cdot 163$ & 6.77 \\
\hline 27 & $7 \cdot 38$ & $57 \cdot 85$ & $3 \cdot 46$ & $6 \cdot 42$ & $10 \cdot 76$ & $21 \cdot 51$ & $1 \cdot 373$ & $9 \cdot 01$ \\
\hline 28 & $7 \cdot 20$ & $63 \cdot 57$ & $3 \cdot 37$ & $8 \cdot 50$ & $7 \cdot 63$ & 16.93 & $1 \cdot 745$ & $7 \cdot 48$ \\
\hline 29 & $7 \cdot 38$ & $53 \cdot 18$ & $4 \cdot 28$ & 8.69 & $11 \cdot 24$ & $22 \cdot 61$ & $1 \cdot 136$ & $6 \cdot 12$ \\
\hline 30 & $6 \cdot 30$ & 59.45 & 4.04 & $8 \cdot 50$ & 9.71 & $18 \cdot 30$ & 1.466 & 7.00 \\
\hline 32 & $6 \cdot 66$ & 70.60 & $3 \cdot 14$ & 6.88 & $8 \cdot 72$ & 10.63 & 2.400 & $10 \cdot 26$ \\
\hline 33 & $6 \cdot 84$ & 55.40 & $3 \cdot 80$ & $10 \cdot 23$ & $7 \cdot 49$ & 23.08 & $1 \cdot 242$ & 5.42 \\
\hline 35 & $6 \cdot 48$ & $65 \cdot 10$ & $3 \cdot 01$ & 7.72 & $8 \cdot 47$ & $15 \cdot 70$ & $1 \cdot 865$ & $8 \cdot 43$ \\
\hline 36 & $7 \cdot 20$ & $58 \cdot 31$ & $4 \cdot 29$ & 8.71 & $9 \cdot 96$ & 18.73 & 1.400 & $6 \cdot 69$ \\
\hline 37 & $6 \cdot 30$ & $69 \cdot 50$ & $2 \cdot 86$ & 5.92 & $7 \cdot 44$ & $14 \cdot 28$ & $2 \cdot 280$ & $11 \cdot 74$ \\
\hline 38 & $7 \cdot 74$ & 48.94 & $5 \cdot 37$ & $12 \cdot 63$ & $12 \cdot 26$ & $20 \cdot 80$ & 0.959 & $3 \cdot 87$ \\
\hline 39 & $6 \cdot 30$ & $64 \cdot 00$ & $3 \cdot 87$ & $8 \cdot 34$ & 10.74 & $13 \cdot 05$ & $1 \cdot 780$ & $7 \cdot 67$ \\
\hline 40 & $7 \cdot 20$ & $62 \cdot 17$ & 3.25 & $8 \cdot 22$ & $7 \cdot 32$ & 19.04 & 1.640 & 7.56 \\
\hline 41 & $7 \cdot 38$ & 72.71 & 2.99 & $6 \cdot 06$ & $7 \cdot 92$ & $10 \cdot 32$ & $2 \cdot 660$ & $12 \cdot 00$ \\
\hline 42 & $6 \cdot 84$ & $73 \cdot 80$ & $2 \cdot 63$ & $4 \cdot 55$ & 7.59 & $11 \cdot 44$ & $\overline{2} \cdot 740$ & $16 \cdot 22$ \\
\hline 45 & $\begin{array}{l}7 \cdot 02 \\
7.02\end{array}$ & 72.43 & $2 \cdot 89$ & $6 \cdot 35$ & $\begin{array}{r}9 \cdot 04 \\
10.20\end{array}$ & $9 \cdot 29$ & $2 \cdot 630$ & 11.40 \\
\hline $\begin{array}{l}46 \\
47\end{array}$ & $\begin{array}{l}7.02 \\
8.82\end{array}$ & $\begin{array}{l}577.40 \\
57.61\end{array}$ & $\begin{array}{l}3 \cdot 70 \\
3 \cdot 19\end{array}$ & $\begin{array}{l}8 \cdot 10 \\
5 \cdot 91\end{array}$ & $\begin{array}{l}10 \cdot 20 \\
14 \cdot 29\end{array}$ & $\begin{array}{l}20 \cdot 60 \\
19 \cdot 00\end{array}$ & $\begin{array}{l}1 \cdot 350 \\
1 \cdot 360\end{array}$ & $\begin{array}{l}7 \cdot 09 \\
9 \cdot 75\end{array}$ \\
\hline $\begin{array}{l}47 \\
48\end{array}$ & $7 \cdot 20$ & 61.01 & $2 \cdot 35$ & $8 \cdot 37$ & $\begin{array}{r}14.57 \\
8.57\end{array}$ & 19.69 & 1.560 & $7 \cdot 29$ \\
\hline 49 & 7.74 & $46 \cdot 58$ & $3 \cdot 08$ & $9 \cdot 26$ & $13 \cdot 02$ & 28.06 & 0.872 & 5.03 \\
\hline 50 & $7 \cdot 38$ & $56 \cdot 19$ & $3 \cdot 86$ & 6.69 & $8 \cdot 13$ & $25 \cdot 14$ & $1 \cdot 283$ & $8 \cdot 40$ \\
\hline
\end{tabular}

Fig. 2 (opposite) shows the relationship between the severity of R.A. and the levels of albumin, $\alpha_{2}$ - and $\gamma$-globulins and the albumin $/ \alpha_{2}$ globulin ratio. The remission group values have been inserted between Grades 1 and 2 because this is where their mean seems, in every case, to fit. Considering the small numbers and large scatter, the mean values show surprisingly consistent trends.

A very different picture appeared when the extent of lung lesions was similarly plotted against the various protein fractions (Fig. 3, overleaf); no clear trend is apparent and the histogram suggests that, irrespective of the extent of lung disease, the groups containing the most severe R.A. show also the greatest abnormality of serum proteins. This relationship is even more clearly demonstrated by the curve at bottom left of Fig. 3, the shape of which, derived by plotting for each grade the ratio of mild and inactive to severe rheumatoid cases in the group, so closely resembles the curves in this figure as to raise a doubt whether the lung pathology contribute anything to the serum protein abnormalities.

It will be observed, however, that the trend from Grade II to Grade IV is always in the expected direction and roughly in prolongation of the line (shown dotted) joining the Grade II mean valu to the mean values for the twelve normal subjects: This might be interpreted as implying that subjects in Grades $\mathbf{0}$ and $I$ are in some way atypical, and there is reason to believe that this may be the case In order to collect an adequate number of cases patients with Caplan's syndrome or characteristic lung lesions without arthritis were actively sougf and persuaded to attend for investigation, even is not clinically ill, quite a number being referred by other physicians. No such special effort was made to locate and examine miners with R.A. alon For this reason the latter were probably an ille्d group of men; those seen must at least have beea ill enough to attend our out-patient clinic of the 

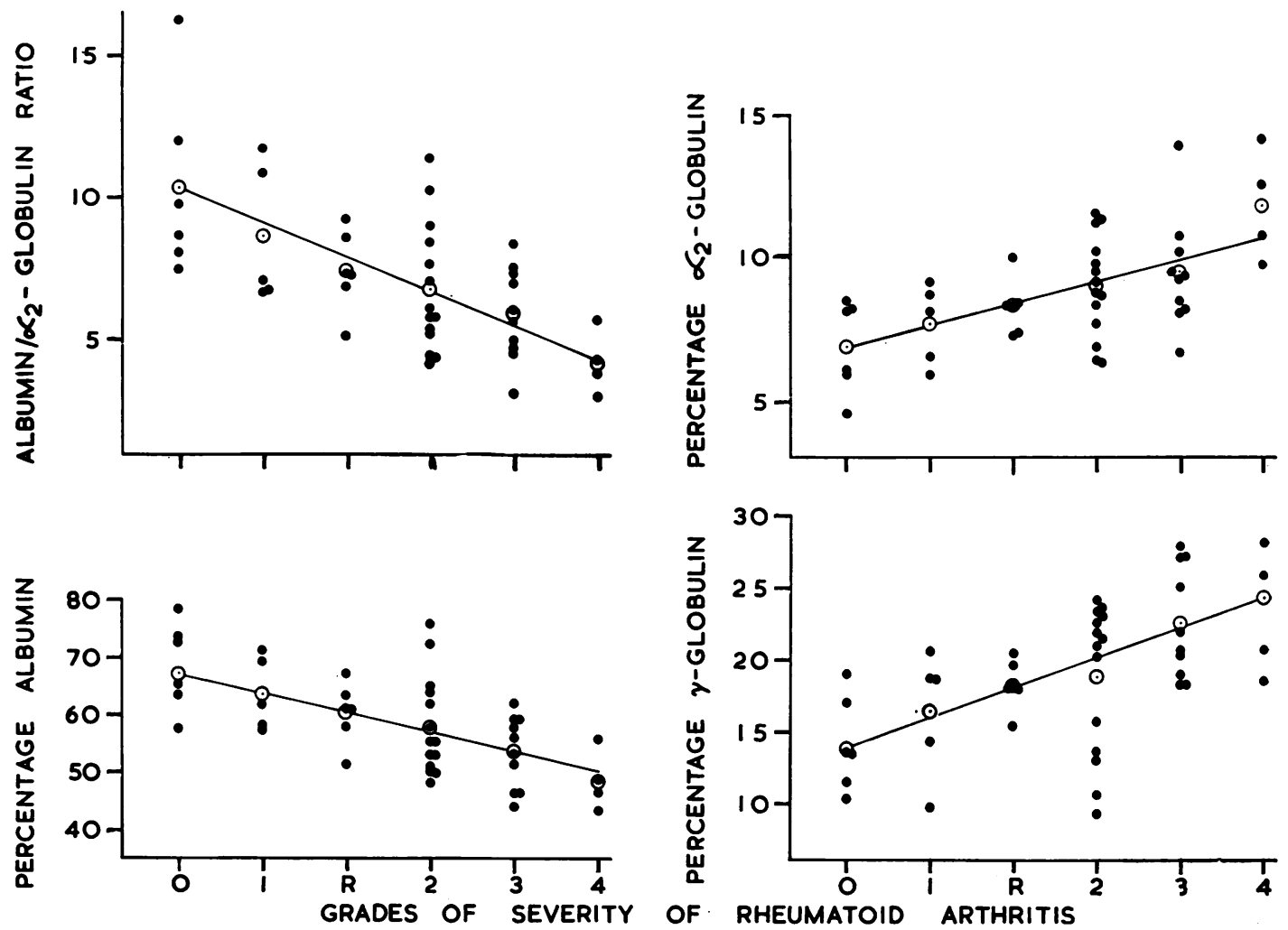

Fig. 2.-Relationship between severity of rheumatoid arthritis and various protein fractions.

own accord or on the advice of their doctor. This biased selection may explain why those without specific lung lesions (Grades 0 and I) show greater abnormality of their serum proteins than do those in Grade II.

The trends from Grade II to Grade IV, where no bias due to selection applies, have been analysed statistically and the results were as follows:

(1) The mean values for the three grades show a significant trend in the case of albumin $(p<0.001)$, $\alpha_{1}$-globulin $(p<0.025), \alpha_{2}$-globulin $(p<0.001), \beta$ globulin $(p<0.05), \gamma$-globulin $(p<0.005)$, and the albumin $/ \alpha_{2}$-globulin ratio $(p<0.001)$.

(2) These trends may, however, consist of two components: an effect of R.A. and an effect of lung lesions. In an attempt to separate the latter, individual regressions were calculated for each protein fraction within each rheumatoid grade. Comparison of these individual "within-group" regression coefficients with each other showed no significant difference for any protein fraction. The weighted average "within-group" regression was therefore taken as an index of lung lesion effect. The values were statistically significant in the case of albumin $(p<0.01), \alpha_{2}$-globulin $(p<0.01), \gamma$-globulin $(p<0.05)$, and the albumin/ $\alpha_{2}$-globulin ratio $(p<0 \cdot 005)$.

(3) Comparison of the mean "within-group" regressions with the slope of the means showed the latter to be always of the same sign and greater than the former. This difference represents the rheumatoid component and was significant in the case of albumin $(p<0.01), \alpha_{2}$-globulin $(p<0.025)$, and the albumin $/ \alpha_{2}$-globulin ratio $(p<0.01)$. In the case of $\gamma$-globulin the difference was significant only at the 10 per cent. level.

From these results it seems justifiable to conclude that the lung lesions are associated with protein changes independent of those due to R.A., at least in the case of albumin, $\alpha_{2}$-globulin, $\gamma$-globulin, and the albumin $/ \alpha_{2}$-globulin ratio. Such protein changes are consistent with the tuberculous theory of their aetiology. Some of the tests are not very discriminatory, and the absence of statistical significance in the case of other protein fractions does not imply that, with a larger sample, a difference would not be found.

Study of the protein patterns of twelve "normal" 

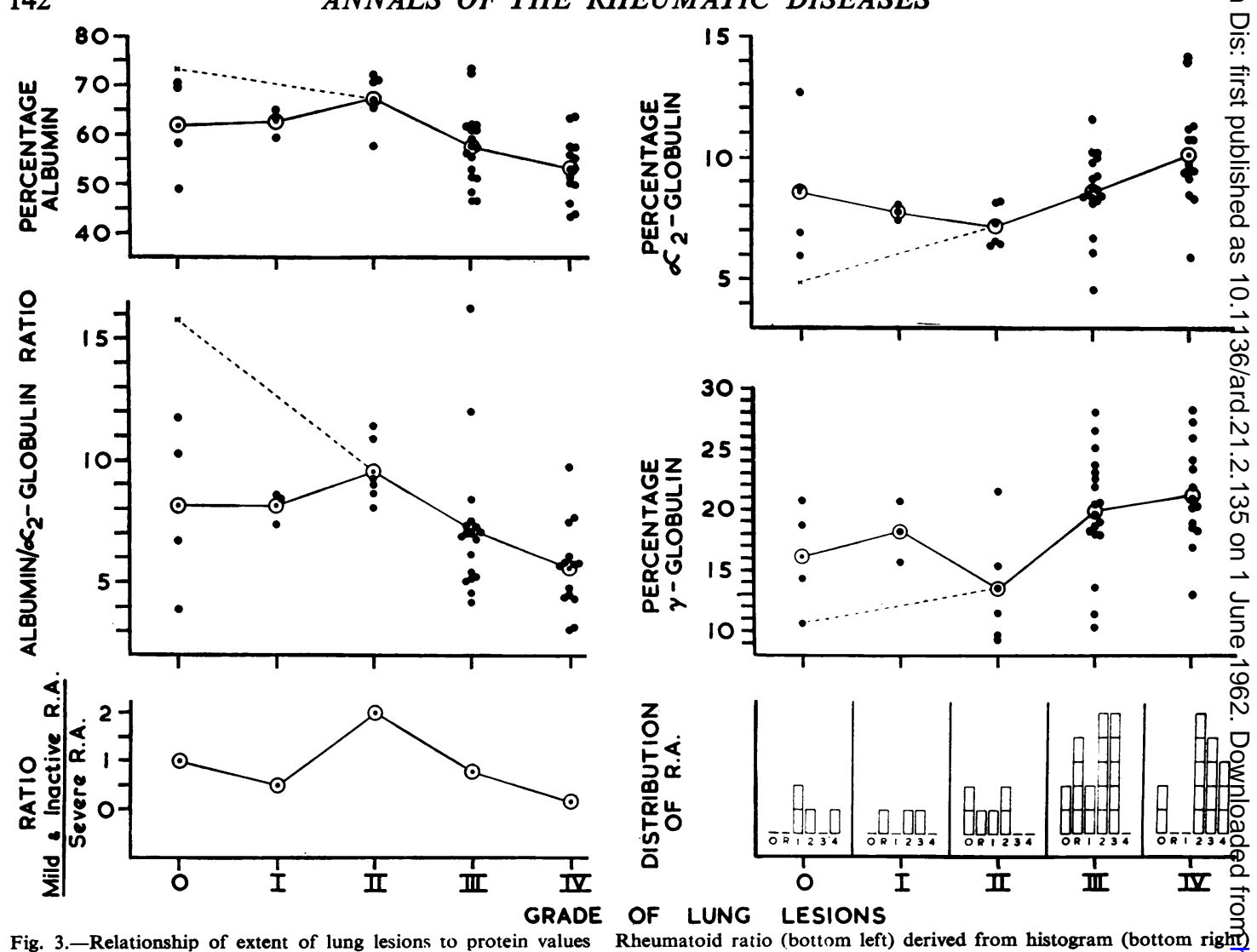

Fig. 3.- Relationship of extent of lung lesions to protein values Rheumatoid ratio (bottom left) derived from histogram (bottom right
by dividing the number in rheumatoid Grades $0, R$ and 1 by the number in Grades 2,3 , and 4 for each lung lesion grade. $\mathrm{X}=$ mean value for twelve normal subjects.

subjects revealed a considerable range of values but little overlap with the values obtained in the group of patients. The results are presented in Table IV (opposite).

No reliable estimate of normal limits or even of a lower limit of normal can be derived from so small a group, but in the single case of the albumin/ $\alpha_{2}$-globulin ratio an attempt has been made to do this approximately.

The $\mathrm{A} / \alpha_{2}$ ratios in Table IV are consistent with a normal distribution, the skewness being small ( $\left.g_{1}=0.76 \pm 2.09\right)$ and, assuming this distribution, it can be calculated that 95 per cent. of normal subjects would have $\mathrm{A} / \alpha_{2}$ ratios above $9 \cdot 24$. This level includes all of the subjects in the "normal group" and excludes all but eight of the 45 patients. Of these eight, all but two fall into arthritis Grades 0,1 , and $R$, the remaining two having Grade 2 arthritis. Only three of them had an abnormal erythrocyte sedimentation rate (above $10 \mathrm{~mm}$./hr), including the two patients with Grade 2 arthritis. This suggests that to set the lower limit of normal for the albumin $/ \alpha_{2}$-globulin ratio at $9 \cdot 24$ would as consistent with clinical observations as can be expected as well as being statistically acceptable and this value was therefore arbitrarily selected. O

The mean values for the twelve normal subjects are compared at the foot of Table IV with those for. 28 normal adults published by Gilliland and others (1956). It is clear that striking differences exis, particularly between the albumin values. This is to be expected since the values published by Gilfiland and his colleagues were derived by direft densitometry, and it has been shown (Gorring 1957) that this method underestimates albumi That albumin has been underestimated is confirmed by the very low $A / G$ ratio given by Gilliland ard others for their normal subjects.

The protein patterns of all the $\mathbf{4 5}$ patients in the present series (though not of all the twelve normal subjects) were analysed by planimetry of densit8meter traces as well as by elution, in order to derige if possible an albumin correction factor whieg could be used in conjunction with the former 
TABLB IV

SERUM PROTEIN ANALYSIS OF TWELVE NORMAL SUBJECTS

\begin{tabular}{|c|c|c|c|c|c|c|c|c|c|}
\hline \multirow{2}{*}{$\begin{array}{l}\text { Case } \\
\text { No. }\end{array}$} & \multirow{2}{*}{$\begin{array}{l}\text { Age } \\
\text { (yrs) }\end{array}$} & \multirow{2}{*}{$\begin{array}{l}\text { Protein } \\
\text { (g. } / 100 \mathrm{ml} .)\end{array}$} & \multicolumn{5}{|c|}{ Serum Protein Fractions } & \multirow{2}{*}{$\underset{\text { Ratio }}{\mathbf{A} / \mathbf{G}}$} & \multirow{2}{*}{$\begin{array}{c}\text { A/ } / \alpha_{2}-\mathrm{G} \\
\text { Ratio }\end{array}$} \\
\hline & & & $\mathbf{A}$ & $\alpha_{1}-G$ & $\alpha_{2}-G$ & $\beta-G$ & $\gamma-G$ & & \\
\hline 1 & 44 & $7 \cdot 38$ & $76 \cdot 55$ & $2 \cdot 83$ & 3.98 & $6 \cdot 70$ & $9 \cdot 94$ & $3 \cdot 264$ & $19 \cdot 24$ \\
\hline 2 & 45 & $7 \cdot 02$ & $74 \cdot 33$ & $3 \cdot 56$ & $4 \cdot 51$ & $5 \cdot 74$ & $11 \cdot 86$ & $2 \cdot 896$ & $16 \cdot 48$ \\
\hline 3 & 40 & $7 \cdot 20$ & $70 \cdot 95$ & $4 \cdot 39$ & $5 \cdot 44$ & $7 \cdot 06$ & $12 \cdot 16$ & $2 \cdot 442$ & $13 \cdot 04$ \\
\hline 4 & 45 & $7 \cdot 56$ & $72 \cdot 00$ & $3 \cdot 81$ & $4 \cdot 89$ & $8 \cdot 11$ & $11 \cdot 19$ & $2 \cdot 571$ & $14 \cdot 72$ \\
\hline 5 & 40 & $7 \cdot 02$ & $73 \cdot 39$ & $3 \cdot 68$ & $5 \cdot 36$ & $9 \cdot 03$ & $8 \cdot 54$ & $2 \cdot 758$ & $13 \cdot 69$ \\
\hline 6 & 44 & $6 \cdot 84$ & $78 \cdot 67$ & 1.62 & $3 \cdot 19$ & $6 \cdot 01$ & $10 \cdot 51$ & $3 \cdot 688$ & $24 \cdot 66$ \\
\hline 7 & 43 & $6 \cdot 66$ & $74 \cdot 00$ & $3 \cdot 01$ & $4 \cdot 00$ & $7 \cdot 99$ & $11 \cdot 00$ & $2 \cdot 846$ & $18 \cdot 50$ \\
\hline 8 & 42 & $7 \cdot 20$ & $75 \cdot 92$ & $2 \cdot 27$ & $4 \cdot 45$ & $7 \cdot 31$ & 10.05 & $3 \cdot 152$ & $17 \cdot 06$ \\
\hline 9 & 49 & $6 \cdot 66$ & $69 \cdot 36$ & $3 \cdot 68$ & $5 \cdot 20$ & $10 \cdot 12$ & $11 \cdot 64$ & $2 \cdot 262$ & $13 \cdot 34$ \\
\hline 10 & 48 & $7 \cdot 56$ & $67 \cdot 28$ & $4 \cdot 19$ & $7 \cdot 02$ & $10 \cdot 73$ & $10 \cdot 78$ & $2 \cdot 057$ & $9 \cdot 59$ \\
\hline 11 & 42 & $6 \cdot 66$ & $72 \cdot 08$ & $3 \cdot 51$ & $6 \cdot 00$ & $7 \cdot 86$ & $10 \cdot 55$ & $2 \cdot 582$ & $12 \cdot 01$ \\
\hline 12 & 43 & $6 \cdot 48$ & $75 \cdot 18$ & $3 \cdot 03$ & $4 \cdot 46$ & $7 \cdot 08$ & $10 \cdot 25$ & $3 \cdot 029$ & $16 \cdot 86$ \\
\hline Total & 525 & $84 \cdot 24$ & $879 \cdot 71$ & $39 \cdot 58$ & $58 \cdot 50$ & $93 \cdot 74$ & $128 \cdot 47$ & $33 \cdot 547$ & $189 \cdot 19$ \\
\hline Mean & $43 \cdot 75$ & $7 \cdot 02$ & $73 \cdot 31$ & $3 \cdot 30$ & $4 \cdot 88$ & $7 \cdot 81$ & $10 \cdot 71$ & $2 \cdot 796$ & $15 \cdot 78$ \\
\hline \multicolumn{2}{|c|}{$\begin{array}{l}\text { Mean Values of Gilliland } \\
\text { and others (1956) }\end{array}$} & $7 \cdot 26$ & $57 \cdot 17$ & $3 \cdot 99$ & $8 \cdot 13$ & $11 \cdot 43$ & $19 \cdot 28$ & $1 \cdot 34$ & $7 \cdot 06$ \\
\hline \multicolumn{2}{|c|}{$\begin{array}{l}\text { Mean Values of Gilliland } \\
\text { and others after Albumin } \\
\text { Correction }\end{array}$} & & $68 \cdot 60$ & $2 \cdot 92$ & $5 \cdot 96$ & $8 \cdot 38$ & $14 \cdot 14$ & $2 \cdot 18$ & $11 \cdot 51$ \\
\hline
\end{tabular}

technique. It was found that no single factor could be successfully applied in every case; indeed the factors required to correct the albumin values in individual cases ranged from $\times 1$ to nearly $\times 2$. The mean correction factor, however, was $\times 1 \cdot 2$, and this can legitimately be applied to the mean of a number of analyses. This has been done with the mean normal values published by Gilliland and others (1956). It will be seen that this manœuvre greatly reduces the differences between the two series, but does not eliminate them.

Comparison of Fig. 1 with traces published by Gilliland and others reveals a difference which may explain part, if not all, of the remaining discrepancy; the densitometer traces obtained in the present series approach closer to the base-line in the troughs between peaks, although that chosen as Fig. 1 shows this feature to a less than average extent. This would have a relatively greater effect upon the low globulin peaks than upon the high albumin peaks, and so tend still further to reduce the $A / G$ and $A / \alpha_{2}$ ratios in the series of Gilliland and others, compared with those in the present series.

\section{Erythrocyte Sedimentation Rate}

When the erythrocyte sedimentation rate values are plotted against the grades of R.A. (Fig. 4, overleaf), the expected rising curve is found, except that a fall occurs from Grade 3 to 4 . The probable explanation of this fall is that some of the Grade 4 cases, though severely disabled by the disease, are tending towards a "burnt-out" stage in which the E.S.R. falls. Alternatively, the explanation may lie in the small number of cases in Grade 4. It is of interest that the mean E.S.R. of the Remission group is the same as that of the group without arthritis, whereas the serum proteins of the Remission group showed greater abnormalities than the group with Grade 1 active arthritis. This suggests that the serum protein pattern reverts to normal more slowly than the E.S.R. when remission of R.A. occurs.

Fig. 4 also shows the E.S.R. plotted against the severity of lung disease. The result is similar to that of the $\mathrm{A} / \alpha_{2}$ ratio similarly plotted (Fig. 3) in that Caplan Grade II cases show the least abnormality in both. No doubt this also can be attributed to the method of selection tending to make lung lesion Grades 0 and I an iller group than Grade II.

Gilliland and others (1956) showed that the albumin $/ \alpha_{2}$-globulin ratio was a better index of the severity of pulmonary tuberculosis than the E.S.R., since 50 per cent. of their cases had a normal E.S.R. whilst only 10 per cent. had a normal $\mathrm{A} / \alpha_{2}$ ratio. 

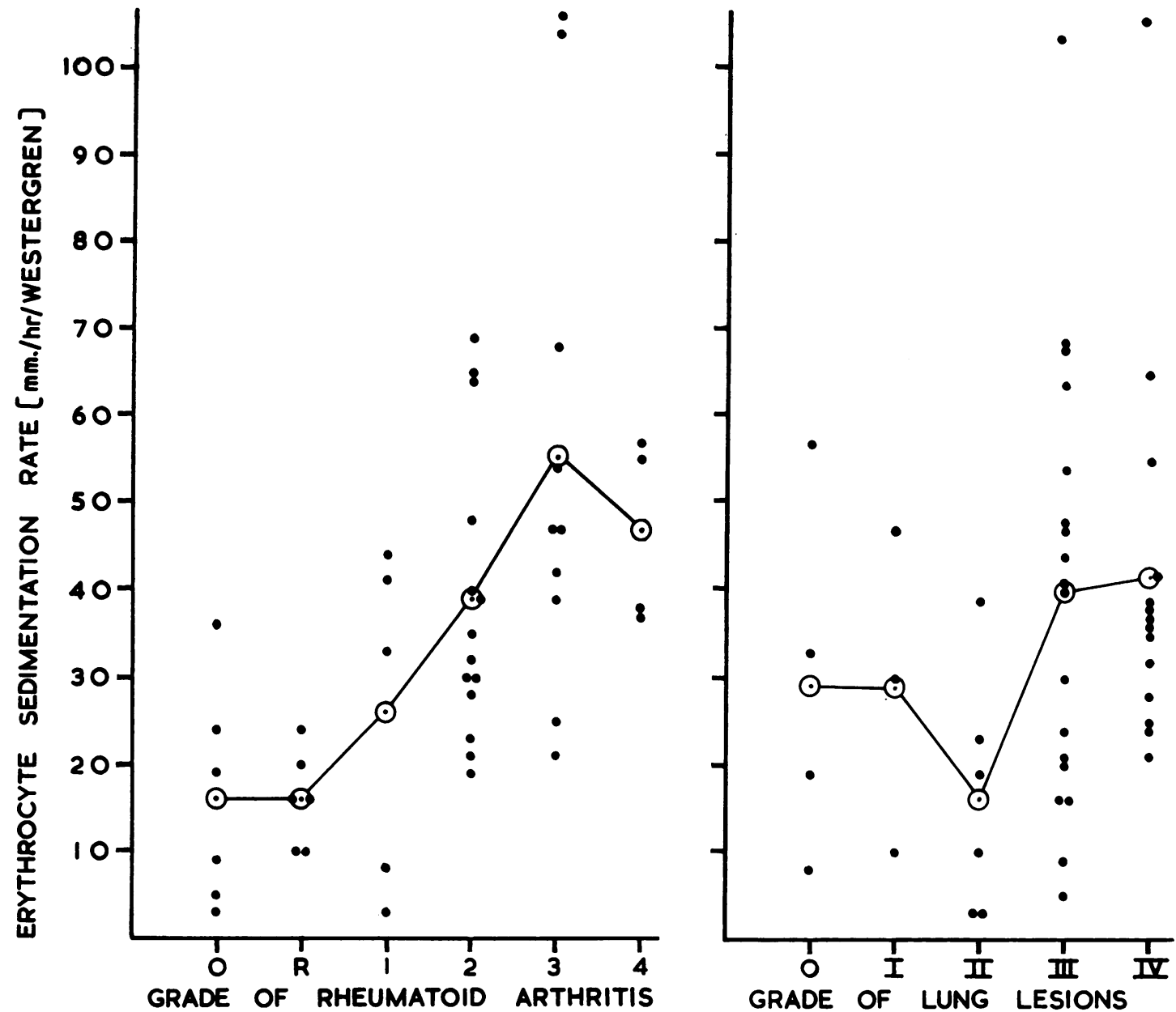

Fig. 4.-Relationship of severity of arthritis (left) and lung lesions (right) to erythrocyte sedimentation rate.

The comparison in the present series is shown in Fig. 5 (opposite). The E.S.R. is normal in seven cases ( $15 \cdot 2$ per cent.) and the $A / \alpha_{2}$ ratio in eight (17.7 per cent.). It therefore appears that in Caplan's syndrome there is little to choose between the two, though remission of R.A. is apparently associated with a more rapid return to normal of the E.S.R. than of the $\mathrm{A} / \alpha_{2}$ ratio.

\section{Sheep Cell Agglutination Test (S.C.A.T.)}

The S.C.A.T. was positive (titre of $1 / 32$ or greater after $18 \mathrm{hrs}$ ) in 33 cases ( 73.4 per cent.). Among the 32 cases of Caplan's syndrome the corresponding figure was 84.4 per cent. Four $(66.6$ per cent.) of the six cases without arthritis, but only two (28.6 per cent.) of the seven patients with arthritis but no definite lung lesions had a positive S.C.A.T오 Table $V$ shows the distribution of positive and negative S.C.A.T.s between those with and those without characteristic lung lesions. The difference is significant at the 1 per cent. level.

$$
\text { TABLE V }
$$

DISTRIBUTION OF POSITIVE AND NEGATIVE S.C.A.T., BY LUNG LESION GRADES

\begin{tabular}{|c|c|c|c|}
\hline \multirow{2}{*}{$\begin{array}{c}\text { Lung Lesion } \\
\text { Grade }\end{array}$} & \multicolumn{3}{|c|}{ S.C.A.T. } \\
\hline & Positive & Negative & Total \\
\hline II-IV $\quad \ldots$ & 31 & 7 & 38 \\
\hline 0 and $I$. & 2 & 5 & 7 \\
\hline Total & 33 & 12 & 45 \\
\hline
\end{tabular}




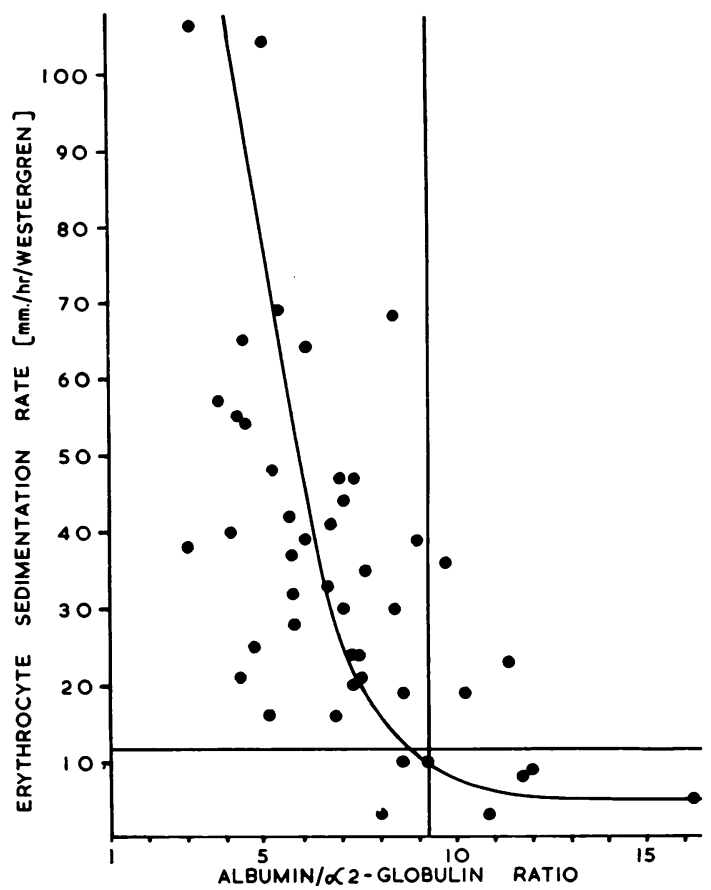

Fig. 5.-Comparison of $A / \propto 2$ ratio with erythrocyte sedimentation rate. Vertical and horizontal lines represent lower limit of normal for $A / \alpha_{2}$ and upper limit of normal for erythrocyte sedimentation rate respectively.

These findings are consistent with those of Ball (1955), and the tendency to which he drew attention for the S.C.A.T. titre to increase with increasing severity of lung lesions was also apparent in the present series (Table VI).

\section{TABLE VI}

PROPORTION OF SUBJECTS WITH HIGH S.C.A.T. TITRES, BY LUNG LESION GRADES

\begin{tabular}{lr|c|c|c|c|c}
\hline Lung Lesion Grade & 0 & I & II & III & IV \\
\hline $\begin{array}{l}\text { Percentage of High Titres } \\
(1 / 256 \text { and above })\end{array}$ & 0 & 0 & 17 & 28 & 36 \\
\hline
\end{tabular}

Though Franklin, Kunkel, and Ward (1958) found the quantity of rheumatoid factor in the serum of their patients to correlate well with the $\gamma$-globulin level and indeed to account for a large part of the elevation of $\gamma$-globulin above normal, no correlation could be demonstrated in the present series between S.C.A.T. titres and the $\gamma$-globulin level $(p>0 \cdot 1)$. Instead there was a suggestion of a correlation with $\beta$-globulin (Fig. 6) and this proved to be significant $(p=0 \cdot 05)$.

That the S.C.A.T. should be significantly cor-
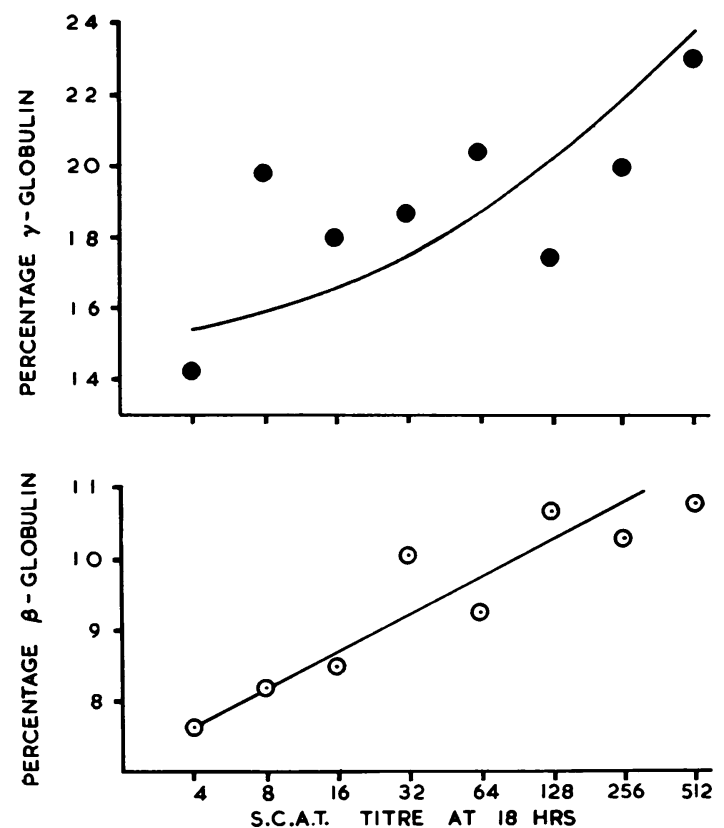

Fig. 6.-Relationship between $\gamma$-globulin and $\beta$-globulin and inverse of S.C.A.T. titre.

related with both the lung lesion grade and the $\beta$-globulin level is surprising in view of the absence of independent correlation between the two latter. Fig. 7 (overleaf) shows the curve when the $\beta$-globulin level is plotted against lung lesion grades and, if Grades 0 and $I$ are disregarded because of the bias introduced by selection into these groups (as was done in the analysis of other protein fractions), the trend from Grade II to Grade IV is significant at the 5 per cent. level $(0.05>p>0.025)$. This trend could be due in part to the effect of arthritis, which can be shown to be on average more severe in those with severe lung lesions, and when the attempt was made statistically to separate the effects of the two no significant correlation could be demonstrated between lung lesions alone (weighted average within-group regression) and the $\beta$-globulin level. On the other hand, there is no significant correlation between the rheumatoid grade and the $\beta$-globulin level $(p>0 \cdot 25)$, so that the trend from Grade II to Grade IV in Fig. 7 may be acceptable at its face value even though this could not be demonstrated statistically.

Accepting for the moment that Fig. 7 shows a true relationship, an interesting three-fold association emerges between severity of lung lesions, S.C.A.T. titre, and $\beta$-globulin level. An attempt has been made in Fig. 8 to show this relationship in the form of a three-dimensional histogram. The 


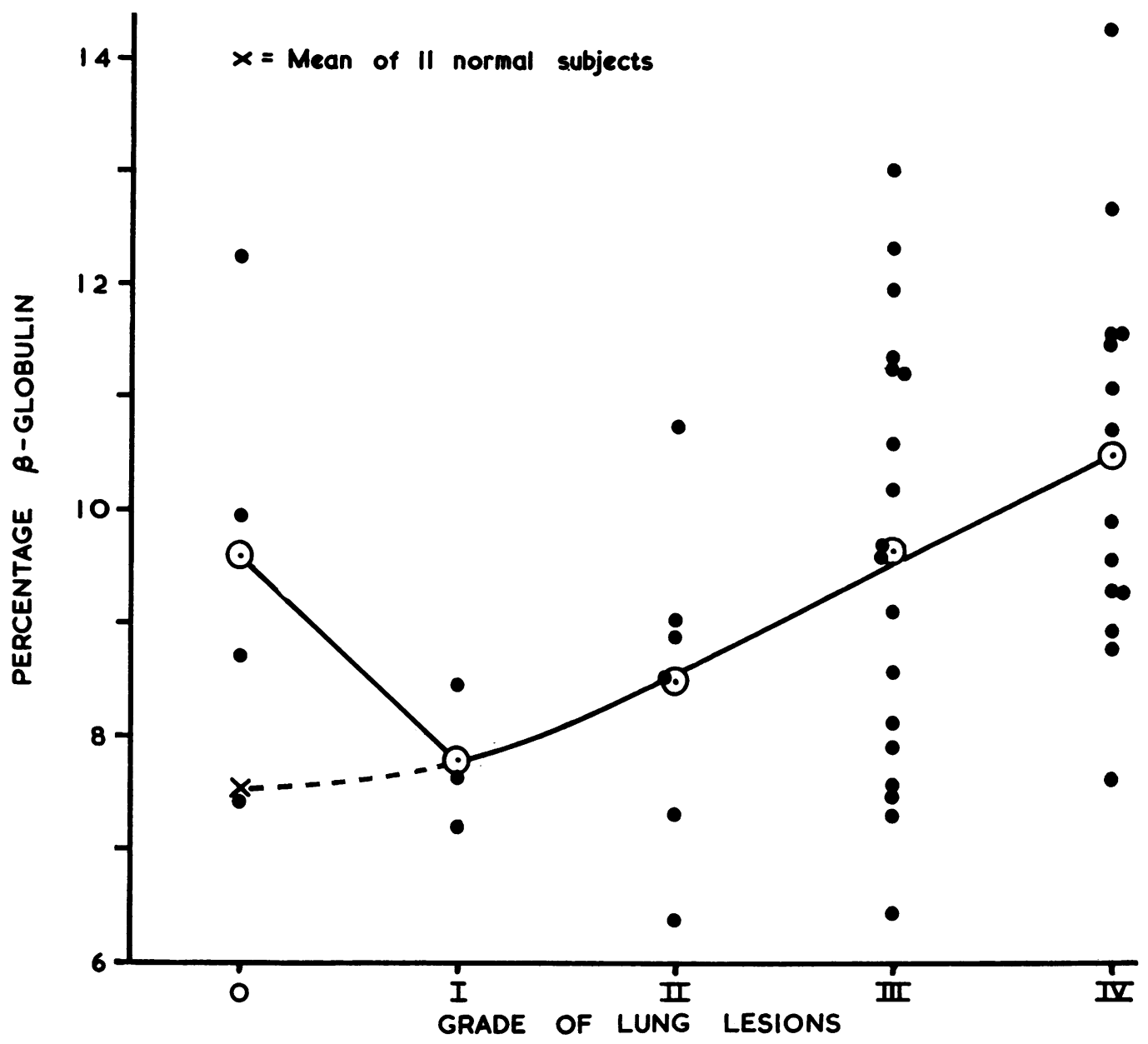

Fig. 7.-Relationship of severity of lung lesions to $\beta$-globulin level.

height of each block represents the mean $\beta$-globulin level of the subjects in the group defined by their lung lesion and S.C.A.T. status. Though the numbers represented by each block are small and those at the left and bottom of the diagram are subject to the same selection bias as has been mentioned before, there remains a strong suggestion of a rising trend from the bottom left to the top right of the diagram. It is hoped to show that there is nothing improbable about such an association.

\section{Rheumatoid Nodules}

Definite subcutaneous rheumatoid nodules were present in sixteen (41 per cent.) of the 39 patients with arthritis and in none of those without it. This rather high incidence probably reflects the care taken to search for nodules and the relativels strict criteria used in the diagnosis of R.A. rather. than any increased tendency for Welsh miners to develop subcutaneous nodules.

The S.C.A.T. was positive in all but one of these sixteen cases, which is consistent with the observato tion of other workers that the test is rarely negative in patients with rheumatoid nodules (Ball, 1952: Jacobson, Kammerer, Wolf, Epstein, and Hellef 1956; Kellgren and Ball, 1959).

Only one subject (Case 36) with subcutaneous nodules was without nodular lung lesions, and i this case the joint symptoms and nodules had beep present for only 2 days. This was also the onlo patient with a negative S.C.A.T. 


\section{Psoriasis and Other Skin Diseases}

Six (13.3 per cent.) of the 45 patients had definite psoriasis, compared with three cases of allergic skin disorders. There was one case each of familial ichthyosis and herpes zoster. This incidence of psoriasis is very high compared with that usually reported. For example, Ball (1952) found only six out of 178 males with R.A. to have psoriasis, and Gribble (1955) reported $4 \cdot 2$ per cent. in his own series, and quoted values between 2.6 and 4.6 per cent. from six other series.

Among the six males and eight females similarly affected in the series reported by Ball (1952), only one had a positive S.C.A.T., whereas four of the six cases with psoriasis in the present series had positive S.C.A.T.s. All the four positive cases had characteristic rheumatoid lung lesions and the two negative cases did not.

\section{Family History}

Seven of the 45 patients gave positive family histories of R.A. In six cases (13.3 per cent.), parents and/or siblings were affected, which agrees with the incidence reported by Miall (1955). The seventh positive history referred to a maternal grandmother. All but one of the seven cases suffered themselves from arthritis. Only four of the cases in the present series were included in the series reported by Miall (1955); one of these had a positive family history.

\section{Age at Onset}

It was already known (Miall and others, 1953) that either the lung lesions or the arthritis may develop many years before the other condition. In the present series an effort has been made to determine the age at onset of each manifestation of disease. In the case of arthritis this was usually a simple matter, as a patient can generally give a fairly accurate estimate of when arthritis first developed. In the case of lung lesions, however, it was only rarely possible, by examination of old radiographs, to date the onset within a year, and in most cases only a minimum duration could be arrived at because the characteristic lesions were already present at the date of the first available radiograph.

In spite of this limitation, it is possible to say (Table VII) that the lung lesions certainly developed first in 29 cases and that the arthritis preceded them in only six cases; in four of the latter, lung lesions remained absent at the time of examination. In the remaining 10 cases in which the order of appearance was doubtful, there is a strong probability that the arthritis developed first in one case. In the remainder there is no evidence either way. Even if we assume that the arthritis preceded the lung lesions in all the doubtful cases, the latter developed first nearly twice as often.

TABLE VII

AGE AT ONSET AND DURATION OF DISEASE IN FIFTY CASES

\begin{tabular}{|c|c|c|c|c|c|}
\hline \multirow[b]{2}{*}{ No. } & \multirow{2}{*}{$\begin{array}{l}\text { Age } \\
\text { (yrs) }\end{array}$} & \multicolumn{2}{|c|}{ Years since Onset } & \multicolumn{2}{|c|}{ Age at Onset } \\
\hline & & $\begin{array}{l}\text { of } \\
\text { Lung } \\
\text { Lesions }\end{array}$ & $\begin{array}{l}\text { of } \\
\text { Rheumatoid } \\
\text { Arthritis }\end{array}$ & $\begin{array}{c}\text { of } \\
\text { Lung } \\
\text { Lesions }\end{array}$ & $\begin{array}{c}\text { of } \\
\text { Rheumatoid } \\
\text { Arthritis }\end{array}$ \\
\hline $\begin{array}{r}1 \\
2 \\
3 \\
4 \\
5 \\
6 \\
7 \\
8 \\
9 \\
10 \\
11 \\
12 \\
13 \\
14 \\
15 \\
16 \\
17 \\
18 \\
20 \\
21 \\
22 \\
23 \\
24 \\
25 \\
26 \\
27 \\
28 \\
29 \\
30 \\
32 \\
33 \\
35 \\
36 \\
37 \\
38 \\
39 \\
40 \\
41 \\
42 \\
45 \\
46 \\
47 \\
48 \\
49 \\
50\end{array}$ & $\begin{array}{l}35 \\
61 \\
56 \\
55 \\
28 \\
42 \\
53 \\
53 \\
43 \\
42 \\
47 \\
34 \\
43 \\
53 \\
46 \\
46 \\
40 \\
39 \\
47 \\
49 \\
59 \\
57 \\
43 \\
44 \\
58 \\
66 \\
43 \\
59 \\
49 \\
59 \\
63 \\
63 \\
64 \\
50 \\
33 \\
45 \\
44 \\
58 \\
51 \\
34 \\
50 \\
61 \\
36 \\
51 \\
60\end{array}$ & $\begin{array}{c}\frac{1}{12} \\
2+ \\
2+ \\
15 \\
9 \\
10 \\
11+ \\
3+ \\
5+ \\
6+ \\
3+ \\
1+ \\
2+ \\
5+ \\
5+ \\
3+ \\
7+ \\
9+ \\
5+ \\
5+ \\
3+ \\
5+ \\
10+ \\
2+ \\
1 \\
4+ \\
7+ \\
3+ \\
4+ \\
7+ \\
7+ \\
8+\end{array}$ & 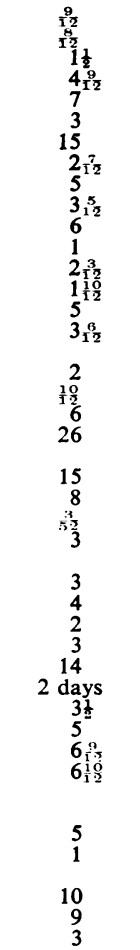 & $\begin{array}{l}35 \\
59- \\
54- \\
40 \\
19 \\
32 \\
42- \\
50- \\
38- \\
36- \\
44- \\
33- \\
42- \\
48- \\
41- \\
43- \\
33- \\
30- \\
42- \\
44- \\
56- \\
52- \\
33- \\
42- \\
57 \\
62- \\
36- \\
56- \\
45- \\
56- \\
55-\end{array}$ & $\begin{array}{l}34 \\
60 \\
54 \\
50 \\
21 \\
39 \\
38 \\
50 \\
38 \\
39 \\
41 \\
33 \\
41 \\
51 \\
41 \\
42 \\
37 \\
46 \\
43 \\
33 \\
28 \\
36 \\
58 \\
63 \\
56 \\
45 \\
57 \\
60 \\
49 \\
64 \\
46 \\
28 \\
38 \\
37 \\
\\
29 \\
49 \\
26 \\
42 \\
57\end{array}$ \\
\hline
\end{tabular}

\section{Discussion}

In 1955, when this investigation was undertaken, the objective evaluation of rheumatoid activity had not been sufficiently developed to inspire confidence. It was therefore decided to attempt only what could be achieved; after the condition had been diagnosed clinically and the diagnosis confirmed serologically and/or radiologically where possible, a case was designated active or inactive (i.e. in remission). This limitation was all the more necessary because several objective criteria, such as the erythrocyte sedimentation rate, haemoglobin level, white cell count, and body temperature, could not be used as indices of activity in case they were influenced by the pulmonary pathology which was a feature of most cases. 
It is not claimed that the criteria used in allocating patients to the active or remission groups were ideal, but they were the best that could be devised at the time. The identical mean erythrocyte sedimentation rate level in the remission group and in the group without arthritis suggests that the method worked well enough.

The design of the trial might more justifiably be criticized on the grounds that the method of selection resulted in those subjects without characteristic pulmonary lesions (i.e. with R.A. alone) not being comparable with those having these lesions. Such selection defects are difficult to avoid when dealing simultaneously with a common and a rare condition. In order to collect adequate numbers of the latter, considerable efforts must be made to locate and examine cases, whereas patients suffering from a common disease such as R.A. present themselves in adequate numbers without any effort being made. In the present series it was realized too late that those coming of their own accord to an out-patient clinic are more likely to be clinically ill than those who have been persuaded to attend because of a reported radiological abnormality. Fortunately, the number of patients without characteristic lung lesions was small in this series, so that to exclude them from certain statistical analyses did not greatly reduce the number available for such analysis. It did, however, have the effect of amputating the tail of all curves relating lung lesion grades to other parameters, so that various grades of severity could be compared only with each other and not with the zero grade as was possible with R.A. This is a severe defect and one which should have been foreseen and guarded against.

A third cause for retrospective regret is that serum electrophoresis was carried out by a method which did not separate the $\beta_{1}$ - and $\beta_{2}$-globulins. The technique described by Laurell, Laurell, and Skoog (1956) was not known to the author until the present study was almost completed but, had this method been used, it seems probable that more convincing evidence of an association between a $\beta$-globulin (probably $\beta_{2}$ ) and the nodular lung lesions of Caplan's syndrome might have been obtained.

For the purposes of this discussion it will be assumed that the trend towards higher total $\beta$ globulin levels with increasing severity of lung lesions shown in Fig. 7 is a true relationship, and it has been shown that the slope from lung lesion Grade II to Grade IV is statistically significant (see p. 141); only when an attempt was made to show that the effect could be attributed to the pulmonary pathology independently of the R.A. did the results fail to achieve significance. The statistical method was admittedly not very discriminatory and the ?? numbers were small, so that failure to achieve $\overrightarrow{\vec{C}}$ significance is quite compatible with a real relation- $\stackrel{0}{\rightarrow}$ ship and there is certainly no evidence that the effect was due to the R.A. Elevation of $\beta$-globulin $\frac{O}{\bar{N}}$ has rarely been claimed to occur in R.A. (Ropes and $\bar{\nabla}$ others, 1954; Kuhns and Crittenden, 1955; Salt, $\stackrel{Q}{~}$ 1956). On the other hand, several workers have os reported high serum $\beta$-globulin levels in the pneumo- $\vec{\circ}$ conioses (Barhad, Vlad, and Dron, 1956; Pernis and Calo, 1956; Rosenkranz, 1957). The series of non- $\vec{\omega}$ pneumoconiotic tuberculous patients reported by Gilliland and others (1956) showed no correlation $\stackrel{0}{2}$ between the $\beta$-globulin level and the radiological ${ }_{-}$ grade. If the apparent relationship between is "Caplan lesions" in the lungs and elevation of the $\vec{\omega}$ serum $\beta$-globulin is indeed a real one, the condition o differs in this respect from tuberculosis.

It is generally assumed that the "rheumatoidfactor" (R.F.) responsible for the agglutination of $\subsetneq$ sensitized sheep erythrocytes is to be found in the $\overparen{D}$ $\gamma$-globulin fraction, and 7 years ago Svartz and $\overrightarrow{0}$ Schlossmann (1955) claimed to have demonstrated $\stackrel{\curvearrowright}{N}$ this experimentally; yet in the present series the S.C.A.T. titre showed significant correlation with the $\beta$-globulin level, but not with the $\gamma$-globulin. Examination of the literature revealed that in $1957 \stackrel{0}{0}$ there were two quite distinct schools of thought on $\frac{}{\Phi}$ this subject; one group of workers claimed to have $\stackrel{\varrho}{\Rightarrow}$ shown R.F. to be a $\gamma$-globulin (Svartz and Schloss-o mann, 1955; Lamont-Havers, 1955; Lospalluto and 3 Ziff, 1956; Franklin, Holman, Müller-Eberhard, and Kunkel, 1957) and another group contended that it was a $\beta$-globulin (Wager and Alameri, 1953; Robinson, Stulberg, and Kuyper, 1954; Heller, $\frac{0}{\sigma}$ Kolodny, Lepow, Jacobson, Rivera, and Marks, 1955; Thulin, 1955; Clark, Smyth, and Haiby, 1957).

Ziff (1957) attempted to reconcile the discrepanto findings of the workers quoted above by the suggestion "that in whole serum the rheumatoid factoro interacts with faster-moving proteins which raise its mobility, while in fractions containing only gammaos globulin it remains with this fraction". This N explanation does not fit the facts, for among the స్ protagonists of $\gamma$-globulin only Lamont-Havers $\omega$ (1955) claimed to have used a fraction "containing only gamma globulin", whereas of the $\beta$-globulin school only Thulin (1955) used "whole serum". The fraction used by Wager and Alameri (1953) was 0 probably more nearly pure $\beta$-globulin than theo fraction used by Svartz and Schlossmann (1955) was pure $\gamma$-globulin.

A more probable explanation of the paradox iso 
suggested by the work of Laurell and others (1956). These workers observed that storage of serum in the liquid state even at $4^{\circ} \mathrm{C}$. resulted in a diminishing level of $\beta_{2}$-globulin with a corresponding increase in $\gamma$-globulin; this was apparent after as little as 2 days' storage. No such shift of $\beta$ to $\gamma$ occurred when serum was stored frozen solid. In the present study all serum specimens were placed in the deep freeze immediately after separation and remained there frozen solid until use.

Few, if any, of the authors quoted above describe how their serum specimens were stored, but among those who favour the belief that R.F. is a $\gamma$-globulin the method of preparing the fractions studied involved prolonged exposure of the serum to temperatures well above its freezing point. It is probable that this allowed time for much if not all of the R.F. to change from a $\beta_{2}$ - into a $\gamma$-globulin; the methods of separation may even have contributed towards this change, for it is noticeable that waterdilution methods were not used by any of the workers of the $\beta$-globulin school. The electrophoretic constitution of the euglobin fraction used by Ziff, Brown, Lospalluto, Badin, and McEwen (1956) does not appear to have been published, but its preparation alone occupies 48 hours, and the demonstration by Lospalluto and Ziff (1956) that its active constituent was a $\gamma$-globulin involved cellulose ion exchange chromatography which must have meant its remaining longer still in the liquid state. In this connexion it is relevant that Franklin and others (1958), and Kunkel, Simon, and Fudenberg (1958), who estimated euglobulin by a turbidimetric method occupying only 30 minutes, found that the quantity of this fraction correlated better with the results of agglutination tests than did the quantity of $\gamma$-globulin. Moreover, Shetlar, Payne, Padron, Felton, and Ishmael (1956), who used a euglobulin fraction prepared by the method of Ziff and others (1956), found a negative correlation between the haemagglutination titre obtained with it and the $\gamma$-globulin content of the fresh serum. This suggests that the R.F. was not contained in the $\gamma$-globulin fraction before it was subjected to the procedures involved in the preparation of euglobulin.

Most recent studies have supported the $\gamma$-globulin school, but this is hardly surprising since the increasing refinement and complexity of the techniques employed will inevitably have involved more prolonged manipulation of liquid serum, permitting ample time for the $\beta_{2}$ - to $\gamma$-globulin transformation to take place. The methods used ranged from the simple but quite lengthy continuous flow electrophoresis employed by Rantz, Randall, and Kettner (1959), who decided that R.F. was a fast-moving $\gamma$-globulin, to the five-stage separations used by Williams, Stewart, and Jenkins (1958) and by Heimer, Federico, and Freyberg (1958). The latter produced a final product with more than 550 times the specific activity of the parent serum and apparently identical with the material isolated by Lospalluto and Ziff (1956). This was said to be a slow $\gamma$-globulin which, after the treatment it had received, was perhaps not surprising. Even such prominent protagonists of the $\gamma$-globulin school as Franklin and others (1958) have shown that, when agglutinating activity is sought in fractions separated by simple starch-block electrophoresis, activity extends from the $\gamma$-globulin almost to the $\beta$-globulin peak, and they admit that the normal 19S component was absent from electrophoretically separated $\gamma$-globulin, being replaced by a $22 \mathrm{~S}$ peak, though the $19 \mathrm{~S}$ component had been demonstrated in the ultracentrifugal pattern of the whole serum.

If R.F. is a $\gamma$-globulin, one would expect it to be contained in Cohn Fraction II, but this does not appear to be the case; F.II is used in many of the precipitation and agglutination tests as a source of "reactant", but no test has been devised in which F.II alone provides both reactant and R.F. Both factors are present in euglobulin, as shown by Singer and Plotz (1958), but euglobulin consists of a mixture of globulins of which $\gamma$-globulin is but one.

That agglutination reactions are usually negative in agammaglobulinaemic patients with arthritis might be regarded as supporting the $\gamma$-globulin character of R.F., but McEwen (1958) cast doubt upon the identification of this condition with rheumatoid arthritis. $\mathrm{He}$ also pointed out that many of the patients were children in whom positive agglutination reactions were less common than in adults (Ziff, 1957; Kellgren and Ball, 1959). Further, one of the six arthritic subjects with agammaglobulinaemia reported by Vaughan and Good (1958) agglutinated sensitized sheep cells and sensitized human cells at a titre of $1: 16$, although his $\gamma$-globulin level was the lowest in the series, namely $3 \mathrm{mg}$. per cent. by the sensitive immuno-chemical method.

Finally, Heimer, Schwartz, and Freyberg (1960) reported the case of a patient with hypogammaglobulinaemia and arthritis who had exceptionally high sheep cell and latex agglutination titres $(1: 3,500$ and $1: 112,000$ respectively). On starch-block electrophoresis the active material was mainly $\beta$-globulin, and the 19.7S macroglobulin eluted from sensitized sheep cell stroma "migrated at a significantly higher rate than human $\gamma$-globulin".

From the above it is concluded that R.F. occurs naturally as a $\beta_{2}$-glycoprotein of sedimentation 
constant about $19 \mathrm{~S}$ and that the 22S $\gamma$-globulin reported by so many workers is an artefact produced by manipulation and/or storage of serum in the liquid state. In any case enough has been said to justify the acceptance of the observed correlation between $\beta$-globulin levels and the S.C.A.T. titre. Though based upon less convincing evidence, a probable relationship between the $\beta$-globulin level and the severity of "Caplan lesions" is also suggested. A relationship between these lesions and the S.C.A.T. titre has been previously demonstrated (Ball, 1955) and is confirmed in the present study.

This three-fold relationship, which is presented diagrammatically in Fig. 8, is particularly interesting in the light of the work by Pernis and his colleagues on the hyaline tissue of silicotic lesions. Pernis and Calo (1956) showed a highly significant increase of serum mucoproteins in silicosis and attributed this to fibroblastic activity. On the assumption that these mucoproteins were, more directly, derived from the ground substance of connective tissue
(Pirani and Catchpole, 1951), Pernis and Ghislandi (1956) analysed the non-collagenous protein fractionow. of silicotic hyaline tissue by quantitative paper chromatography of hydrolysates. They showed that its amino-acid constitution corresponded withe that of serum $\beta$-globulin, and Pernis, Bairati, and Frigerio (1956) later confirmed the identification of $\beta$-globulin by $x$-ray diffraction analysis and by electrophoresis. It is particularly interesting that the total carbohydrate and hexosamine content of "Fraction I" prepared by Pernis and Clerici (1957) agrees closely with that found in a similar fraction $\vec{\omega}$ obtained from the fibrinoid material of rheumatoid nodules (Consden, Glynn, and Stanier, 1953).

Kunkel (1958) considered the possibility that R.F. might play a causative role in the pathogenesiș of rheumatoid arthritis, but concluded that there was no evidence to support this. Vaughan (1959) transfused high-titre rheumatoid plasma into volun음 teers and was unable to show any harmful effect.Numerous workers, however, have emphasized the

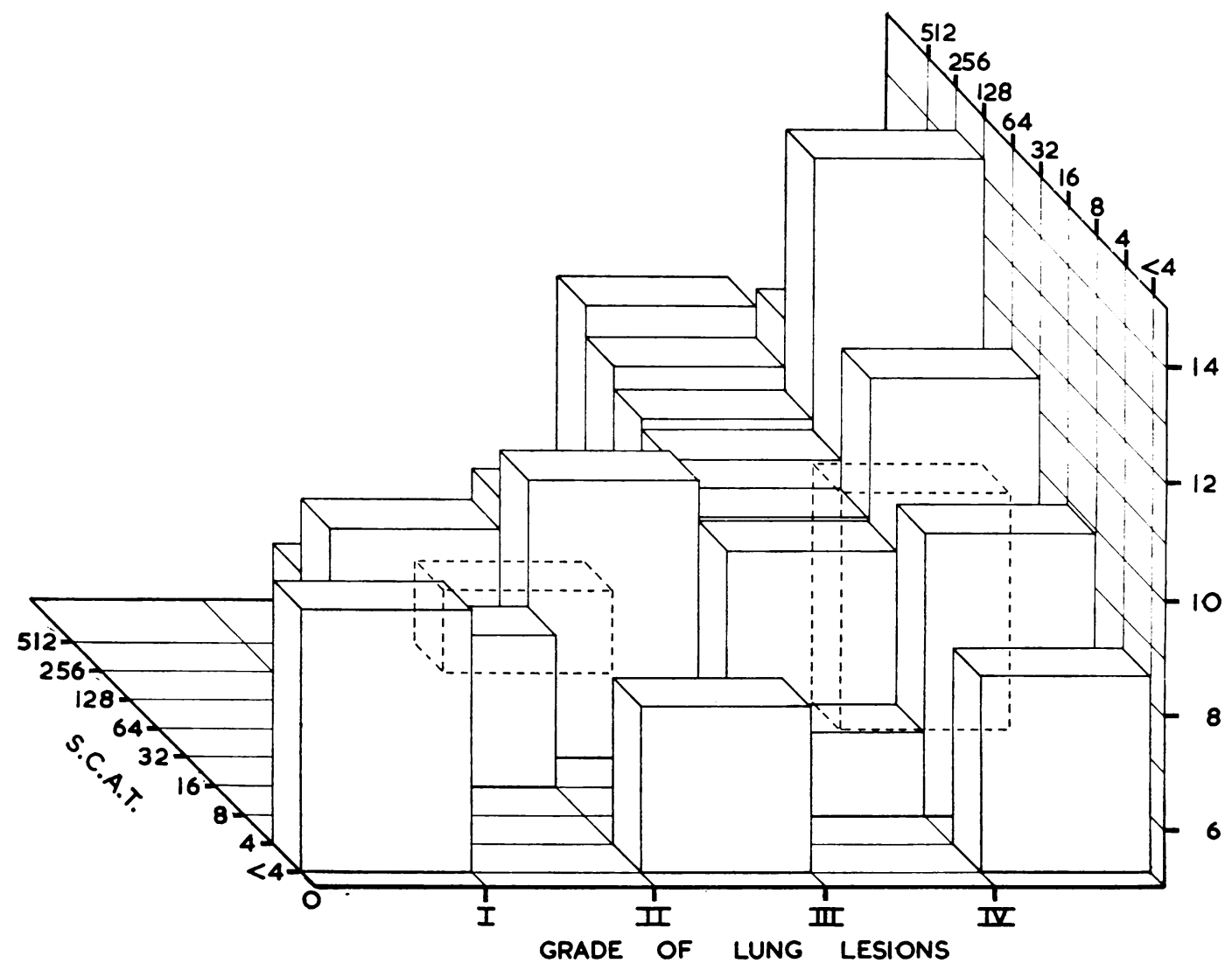

Fig. 8. -Three-dimensional histogram relating lung lesion grades and S.C.A.T. titres to $\beta$-globulin level. 
relationship between positive agglutination reactions and some of the secondary features of rheumatoid disease (Sokoloff and Bunim, 1957; Kunkel, 1958; Christian, 1959; Epstein and Engleman, 1959; Kellgren and Ball, 1959), and in the case of subcutaneous nodules (Kunkel, 1958; Kellgren and Ball, 1959) and "Caplan lesions" (Caplan, 1959) it has been suggested that R.F. may indeed play a causal part.

The mechanism proposed is spontaneous precipitation of R.F.- $\gamma$-globulin complexes in small arterioles followed by inflammation and necrosis. This sounds reasonable, since precipitation of this kind can be demonstrated in vitro when high titres of R.F. activity are present (Epstein, Johnson, and Ragan, 1956; Epstein, Engleman, and Ross, 1957; Mannik, Brine, and Clark, 1958), and in the case of Caplan's syndrome minute particles of mineral dust might facilitate precipitation as Bentonite does in vitro (Bloch and Bunim, 1959). But the lesions attributed to this mechanism can occur in the absence of demonstrable R.F.

Subcutaneous rheumatoid nodules are usually associated with positive agglutination reactions, but in few large series is the association demonstrable in 100 per cent. of cases. Kellgren and Ball (1959) found the S.C.A.T. positive in 100 per cent. of their male patients with nodules, but in only 92 per cent. of the females. Jacobson and others (1956) obtained 95 per cent. positive sheep cell and 92 per cent. positive latex agglutination reactions. Caplan, Cowen, and Gough (1958) found the Rose test negative in a patient with both subcutaneous and pulmonary nodules. In the present series, one of the sixteen patients with subcutaneous nodules $(6 \cdot 7$ per cent.) and eight of the 38 patients with pulmonary nodules $(21.0$ per cent.) had a negative S.C.A.T. It might be argued that, in the few cases showing negative agglutination tests, positive results would have been obtained had the test been done while the nodules were developing. An opportunity arose to do this during the present study:

Case 36, a man aged 64, who was admitted to hospital for treatment of chronic bronchitis associated with simple pneumoconiosis, began complaining of pains in several joints, especially those of the hands and arms, while he was in the ward. Small, soft nodules were present on both elbows and the patient was certain that these had not been there previously. The nodules increased in size during the following week, though joint pains were controlled with small doses of aspirin, and one nodule was then excised for histological examination. The pathologist confirmed our suspicion that the lesion was a rheumatoid nodule, yet the S.C.A.T. performed upon serum collected when the joint symptoms and nodules had been present for only 2 days was completely negative. If R.F. plays a causative role in the development of subcutaneous lesions, it is obviously not the only possible cause.

Patients with Caplan's syndrome in whom fresh pulmonary lesions were just developing were also included in the series, though no patient developed his first lesion while under observation. It was found, however, that the S.C.A.T. was most often positive and the titre highest in patients whose pulmonary lesions were fully developed and often of long standing, as indicated by old radiographs and by confluence of lesions.

This suggests that "Caplan lesions" may be a site of synthesis of R.F., a speculation which is supported by the findings of Mellors, Heimer, Corcos, and Korngold (1959). They attributed the formation of R.F. to the reticulum cells of the germinal centres of some lymphoid follicles and to plasma cells, which they demonstrated by staining with fluorescent antibody, in synovial membrane and subcutaneous rheumatoid nodules. Plasma cells have been shown to be present in large numbers in the peripheral zones of Caplan lesions (Seal, personal communication), but that these cells stain with R.F.specific fluorescent antibody remains to be demonstrated.

\section{Summary}

The British literature on Caplan's syndrome is briefly reviewed, with particular reference to the pathogenesis of the pulmonary lesions, and an investigation is described which was designed to throw fresh light upon this problem.

Statistical analysis of the results revealed an association between the levels of several serum protein fractions and the severity of the lung lesions independently of the severity of the arthritis. Elevation of $\alpha_{2}$ - and $\gamma$-globulin and reduction of albumin and of the albumin $/ \alpha_{2}$-globulin ratio are consistent with the tuberculous theory of the aetiology of these lesions, but a trend was also observed towards higher levels of $\beta$-globulin with increasing severity of pulmonary lesions. Rheumatoid arthritis itself rarely produces this effect and no increase of $\beta$-globulin has been reported in tuberculosis.

The previously observed association between the presence of "Caplan lesions" in the lungs and positive haemagglutination tests for rheumatoid arthritis was confirmed, and a significant correlation was demonstrated between the sheep cell agglutination titre and the $\beta$-globulin level.

The literature on the nature of the rheumatoid factor is reviewed and the conclusion reached that R.F. exists naturally as a 19S macroglobulin migrating electrophoretically as a $\beta_{2}$-globulin, but that transformation to a $22 \mathrm{~S} \gamma$-globulin occurs when serum is stored in the liquid state.

Based on this conclusion and on the three-fold relationship observed between the severity of 
"Caplan lesions", the haemagglutination titre, and the $\beta$-globulin level, a hypothesis is proposed that the nodular lesions described by Caplan, and perhaps some other lesions associated with rheumatoid arthritis such as subcutaneous necrobiotic nodules, may be sites of synthesis of the rheumatoid factor. It is further suggested that the raw material for this synthesis may consist of $\beta$-glycoprotein derived from the ground-substance of degenerating collagenous tissue.

The author wishes to thank Professor J. H. F. Brotherston, Dean of the Faculty of Medicine, University of Edinburgh, for permission to publish this paper which is condensed from a Thesis submitted for the Degree of M.D.

Thanks are also due to Dr. A. Caplan, of the Cardiff Pneumoconiosis Medical Panel, Dr. J. D. Ball, of the Miners' Chest Diseases Treatment Centre, and Dr. Byron Evans, consultant physician at Llandough Hospital, for referring cases. Dr. B. T. Warner and Mr. P. D. Oldham gave invaluable assistance with the statistical analyses, and Dr. J. C. Gilson, Director of the Pneumoconiosis Research Unit, gave encouragement, criticism, and advice at all stages. Dr. J. Ball, of the Rheumatism Research Centre, Manchester University, kindly arranged for all the sheep cell agglutination tests to be carried out in his laboratory, and unstinting secretarial assistance was provided by Miss D. M. Lacey.

\section{REFERENCES}

Ball, J. (1950). Lancet, 2, 520.

(1952). Ann. rheum. Dis., 11, 97.

(1955). Ibid., 14, 159.

Barhad, B., Vlad, A., and Dron, F. (1956). Rev. Fiziol., $3 / 5,520$.

Berg, J. W. (1957). Lancet, 1, 272.

Bloch, K. J., and Bunim, J. J. (1959). J. Amer. med. Ass., 169, 307.

Caplan, A. (1953). Thorax, 8, 29.

- (1959). Proc. roy. Soc. Med., 52, 1111.

- Cowen, E. D. H., and Gough, J. (1958). Thorax, 13, 181.

Christiaens, L., Balgairies, E., Claeys, C., and Lenoir, L. (1954). Rev. méd. min., 7, 14.

Christian, C. L. (1959). Bull. rheum. Dis., 9, 179.

Clark, G. M., Smyth, C. J., and Haiby, G. (1957). Ann. rheum. Dis., 16, 135.

Consden, R. (1957). Lancet, 1, 106.

— and Glynn, L. E. (1955). Ibid., 1, 943.

- - and Stanier, W. M. (1953). Biochem. J., $55,248$.

and Howard, A. (1957). J. clin. Path., $10,178$.

Duthie, J. J. R., Brown, P. E., Knox, J. D. E., and Thompson, M. (1957). Ann. rheum. Dis., 16, 411.

Epstein, W. V., and Engleman, E. P. (1959). Arthr. and Rheum., 2, 250.

,$- \frac{}{16}$, and Ross, M. (1957). Ann. rheum. Dis., 16, 448.
Epstein, W. V., Johnson, A., and Ragan, C. (1956) Proc. Soc. exp. Biol. (N.Y.), 91, 235.

Franklin, E. C., Holman, H. R., Müller-Eberhard, H. J. and Kunkel, H. G. (1957). J. exp. Med., 105, 425 Kunkel, H. G., and Ward, J. R. (1958). Arthr and Rheum., 1, 400.

Gilliland, I. C., Johnston, R. N., Stradling, P., an

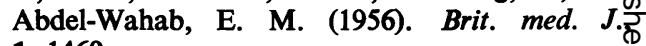
$1,1460$.

Gorringe, J. A. L. (1957). Clin. Chim. Acta, 2, 353. के

Gough, J., Rivers, D., and Seal, R. M. E. (1955) Thorax, 10, 9.

Gribble, M. de G. (1955). Ann. rheum. Dis., 14, 198. $\overrightarrow{\vec{A}}$ Heimer, R., Federico, O. M., and Freyberg, R. H. (1958) $)_{\mathscr{\omega}}$ Proc. Soc. exp. Biol. (N.Y.), 99, 381.

,-- , Schwartz, E. R., and Freyberg, R. H. (1959) Bull. rheum. Dis., 9, 179. Schwartz, E. R., and Freyberg, R. H. (1960) $\overrightarrow{\text { a }}$ Arthr. and Rheum., 3, 274.

Heller, G., Kolodny, M. H., Lepow, I. H., Jacobsonç A. S., Rivera, M. E., and Marks, G. H. (1955)? J. Immunol., 74, 340.

Jacobson, A. S., Kammerer, W. H., Wolf, J., Epstein $\bar{E}^{-}$ W. V., and Heller, G. (1956). Amer. J. Med.尹़ 20, 490.

Kellgren, J. H., and Ball, J. (1959). Brit. med. J. 1, 523.

- and Lawrence, J. S. (1956). Ann. rheum. Dis., 15, 1

Kuhns, W. J., and Crittenden, J. (1955). J. Lab. clino Med., 46, 398.

Kunkel, H. G. (1958). Arthr. and Rheum., 1, 381.

—, Simon, H. J., and Fudenberg, H. (1958). Ibid.ֶ 1, 289.

Lamont-Havers, R. W. (1955). Proc. Soc. exp. Biol (N.Y.), 88, 35.

Laurence, D. J. R. (1954). J. sci. Instrum., 31, 137.

Laurell, C. B., Laurell, S., and Skoog, N. (1956). Clin Chem., 2, 99.

Lospalluto, J., and Ziff, M. (1956). Paper presented a巴 the Annual Meeting of the American Rheumatism? Association, Chicago. June, 1956.

Mannik, M., Brine, K. L., and Clark, W. S. (1958) Arthr. and Rheum., 1, 410.

McEwen, C. (1958). Ibid., 1, 181.

Mellors, R. C., Heimer, R., Corcos, J., and Korngold, L을 (1959). J. Exp. Med., 110, 875.

Miall, W. E. (1955). Ann. rheum. Dis., 14, 150.

$\longrightarrow$, Caplan, A., Cochrane, A. L., Kilpatrick, G. S., an Oldham, P. D. (1953). Brit. med. J., 2, 1231. O

Nethercott, S. E., and Strawbridge, W. G. $(1956) \mathrm{N}$ Lancet, 2, 1132.

Pernis, B., Bairati, A., and Frigerio, G. (1956). Med. $d \stackrel{N}{N}$ Lavoro, 47, 439.

and Calo, S. (1956). Ibid., 47, 5.

and Clerici, E. (1957). Ibid., 48, 238. and Ghislandi, E. (1956). Ibid., 47, 460.

Phillips, R. A., Van Slyke, D. D., Dole, V. P., Emerson K., Hamilton, P. B., and Archibald, R. M. (1944, 1945). "Copper Sulfate Method for Measuring Specific Gravities of Whole Blood and Plasma. Josiah Macy Jr. Foundation, New York. 
Pirani, C. L., and Catchpole, H. R. (1951). Arch. Path., 51, 597.

Prignot, J. (1956). Arch. belges Méd. soc., 14, 1.

Rantz, L. A., Randall, E., and Kettner, D. (1959). Arthr. and Rheum., 2, 104.

Rees, V. H., and Laurence, D. J. R. (1955). Clin. Chem., 1, 329.

Rivers, D., James, W. R. L., Davies, D. G., and Thomson, S. (1957). Brit. J. industr. Med., 14, 39.

Robinson, A. R., Stulberg, C. S., and Kuyper, A. C. (1954). Proc. Soc. exp. Biol. (N.Y.), 85, 4.

Ropes, M. W., Perlmann, G. E., Kaufman, D., and Bauer, W. (1954). J. clin. Invest., 33, 311.

Rosenkranz, K. A. (1957). Beitr. Silikose-Forsch., Heft 48, p. 3.

Salt, H. B. (1956). Clin. Chem., 2, 35.

Seibert, F. B., Seibert, M. V., Atno, A. J., and Campbell, H. W. (1947). J. clin. Invest., 26, 90.

Shaw, D. B. (1956). Brit. med. J., $2,47$.

Shetlar, M. R., Payne, R. W., Padron, J., Felton, F., and Ishmael, W. K. (1956). J. Lab. clin. Med., 48, 194.

Singer, J. M., and Plotz, C. M. (1958). Arthr. and Rheum., 1, 142.

Sokoloff, L., and Bunim, J. J. (1957). J. chron. Dis., $5,668$.

Svartz, N., and Schlossmann, K. (1955). Ann. rheum. Dis., 14, 191.

Thulin, K. E. (1955). Acta rheum. scand., 1, 22.

Vaughan, J. H. (1959). Amer. J. Med., 26, 596.

- and Good, R. A. (1958). Arthr. and Rheum., 1, 99.

Wager, O., and Alameri, E. (1953). Ann. Med. exp. biol. Fenn., 31, 361.

Williams, R. R., Stewart, L. C., and Jenkins, J. C. (1958). Proc. Soc. exp. Biol. (N.Y.), 99, 554.

Ziff, M. (1957). J. chron. Dis., 5, 644.

, Brown, P., Lospalluto, J., Badin, J., and McEwen, C. (1956). Amer. J. Med., 20, 500.

\section{Altérations des protéines sériques dans le syndrome de Caplan}

RÉSUMÉ

On passe brièvement en revue la littérature anglaise sur le syndrome de Caplan, particulièrement en ce qui concerne la pathogénèse des lésions pulmonaires et on décrit des recherches entreprises pour élucider ce problème.

L'analyse statistique des résultats révéla l'existence d'une association entre les niveaux de différentes fractions protéiques du sérum et la gravité des lésions pulmonaires, indépendante de la gravité de l'arthrite. L'augmentation des globulines-a2 et $\gamma$ et la réduction de l'albumine et du rapport albumine/globuline- $\alpha 2$ s'accordent avec la théorie attribuant une origine tuberculeuse à ces lésions, mais on a observé aussi que le taux de la globuline- $\beta$ tend à monter avec la sévérité des lésions pulmonaires. L'arthrite rhumatismale seule ne produit que rarement cet effet et une augmentation de la globuline- $\beta$ au cours de la tuberculose n'a jamais été rapportée.

On confirme l'association, antérieurement observée, entre la présence de "lésions de Caplan" dans les poumons et les réactions positives d'hémagglutination pour l'arthrite rhumatismale et on démontre une corrélation significative entre le titre d'agglutination des érythrocytes de mouton et le taux de globuline- $\beta$.

On passe en revue la littérature concernant la nature du facteur rhumatismal et on conclut que ce facteur existe sous forme d'une macroglobuline 19S, migrante éléctrophorétiquement comme une globuline- $\beta 2$, mais qui se transforme en globuline $\gamma 22 \mathrm{~S}$ pendant la conservation en état liquide.

En se basant sur cette conclusion et sur le triple rapport observé entre la sévérité des "lésions de Caplan", le titre d'hémagglutination et le taux de globuline- $\beta$, on soumet une hypothèse selon laquelle les lésions nodulaires décrites par Caplan, et peut-être certaines autres lésions associées à l'arthrite rhumatismale, telles que des nodules souscutanés necrobiotiques, peuvent être des lieux de synthèse du facteur rhumatismal. On indique, de plus, que la matière première pour cette synthèse pourrait être la glycoprotéine $\beta$, dérivée de la matrice du tissu colagène en dégénérescence.

\section{Cambios en las proteinas séricas en el síndrome de Caplan \\ SUMARIo}

Se revisa brevemente la literatura británica acerca del síndrome de Caplan, particularmente en referencia con la patogénesis de las lesiones pulmonares y se describe una investigación iniciada con el intento de arrojar nueva luz sobre este problema.

El análisis estadístico de los resultados revela una asociación entre los niveles de diferentes fracciones protéicas del suero y la gravedad de las lesiones pulmonares, independiente de la gravedad de la artritis. Elevación de la globulinas-a2 y $\gamma$ y reducción de la albumina $y$ del cociente albumina/globulina- 22 se acuerda con la teoría tuberculosa de la etiología de estas lesiones, pero fué también observada una tendencia hacia niveles más altos de globulina $\beta$ con aumentada severidad de las lesiones pulmonares. La artritis reumatoide por si misma raramente produce este efecto y ningún aumento de globulina- $\beta$ ha sido comunicado en la tuberculosis.

Se confirmó la anteriormente observada asociación entre la presencia de "lesiones de Caplan" en los pulmones y las reacciones positivas de hemoaglutinación para la artritis reumatoide y se comprobó una significante correlación entre el título de aglutinación de los eritrocitos de carnero y el nivel de globulina- $\beta$.

Se revisa la literatura acerca la naturaleza del factor reumático y se concluye que este factor existe naturalmente como una macroglobulina $19 \mathrm{~S}$, migrante electroforéticamente como una globulina- $\beta 2$, pero que la transformación en una globulina $\gamma 22$ S ocurre cuando el suero es almacenado en estado líquido.

Basada en esta conclusión y en la triple relación observada entre la severidad de las "lesiones de Caplan", el título de hemaglutinación y el nivel de globulina $\beta$, se propone una hypótesis de que las lesiones nodulares descritas por Caplan, y quizas algunas otras lesiones asociadas con la artritis reumatoide, tales como nódulos subcutáneos necrobióticos, puedan ser legares de síntesis del factor reumático. Se sugiere últimamente que la materia prima para esta síntesis pudiera consistir en la glicoproteina $\beta$, derivada de la matriz del tejido colágeno en degeneración. 